Article

\title{
Results from On-The-Ground Efforts to Promote Sustainable Cattle Ranching in the Brazilian Amazon
}

\author{
Erasmus K.H.J. zu Ermgassen ${ }^{1, *(1)}$, Melquesedek Pereira de Alcântara ${ }^{2}$, Andrew Balmford ${ }^{1}$, \\ Luis Barioni ${ }^{3}$, Francisco Beduschi Neto ${ }^{4,5}$, Murilo M. F. Bettarello ${ }^{6}$, Genivaldo de Brito ${ }^{7}$, \\ Gabriel C. Carrero ${ }^{2,8}$, Eduardo de A.S. Florence 4 (i), Edenise Garcia 7 (iD), \\ Eduardo Trevisan Gonçalves ${ }^{9}$, Casio Trajano da Luz ${ }^{9}$, Giovanni M. Mallman ${ }^{7}$, \\ Bernardo B.N. Strassburg 10,11, Judson F. Valentim ${ }^{12}$ (i) and Agnieszka Latawiec 10,11,13,14
}

1 Conservation Science Group, Department of Zoology, University of Cambridge,

David Attenborough Building, Pembroke Street, Cambridge CB2 3EQ, UK; apb12@cam.ac.uk

2 Institute for Conservation and Sustainable Development of the Amazon, Rua Barão de Solimões 12, Manaus, AM 69058-250, Brazil; melk.alcantara@idesam.org.br (M.P.d.A.); gabriel.carrero@idesam.org.br (G.C.C.)

3 Embrapa Agriculture Informatics, Av. André Tosello, nº 209, Campus da Unicamp, Campinas, SP 13083-886, Brazil; luis.barioni@embrapa.br

4 Instituto Centro de Vida, Av. Ariosto da Riva, 3473- St E, Alta Floresta, MT 78580-000, Brazil; chicobeduschineto@gmail.com (F.B.N.); florenceaf@hotmail.com (E.d.A.S.F.)

5 Grupo de Trabalho da Pecuária Sustentável, Av. Paulista 1754 -Cj. 146, Bela Vista, SP 01310-920, Brazil

6 Via Verde Consultoria Agropecuária em Sistemas Tropicais, Rua Mariana Amaral 138, São Sebastião do Paraíso, MG 37950-000, Brazil; mbettarello@viaverde.agr.br

7 The Nature Conservancy, Belém, PA 66035-115, Brazil; gdebrito@tnc.org (G.d.B.); egarcia@tnc.org (E.G.); gmallmann@tnc.org (G.M.M.)

8 Department of Geography, University of Florida, 3141Turlington Hall, Gainesville, FL 32611-7315, USA

9 Instituto de Manejo e Certificação Florestal e Agrícola, Estrada Chico Mendes 185, Piracicaba, SP 13426-420, Brazil; eduardo@imaflora.org (E.T.G.); casio@imaflora.org (C.T.d.L.)

10 International Institute for Sustainability, Estrada Dona Castorina 124, Rio de Janeiro, RJ 22460-320, Brazil; b.strassburg@iis-rio.org (B.B.N.S.); a.latawiec@iis-rio.org (A.L.)

11 Rio Conservation and Sustainability Science Centre, Department of Geography and the Environment, Pontifical Catholic University of Rio de Janeiro, Rio de Janeiro, RJ 22453-900, Brazil

12 Embrapa Acre. Rodovia BR-364, km 14, Caixa Postal 321., Rio Branco, SC 69908-970, Brazil; judson.valentim@embrapa.br

13 School of Environmental Sciences, University of East Anglia, Norwich NR4 7TJ, UK

14 Institute of Agricultural Engineering and Informatics, Faculty of Production and Power Engineering, University of Agriculture in Krakow, Balicka 116B, 30-149 Krakow, Poland

* Correspondence: erasmus.zu.ermgassen@gmail.com or ekhjz2@cam.ac.uk; Tel.: +44-01223-765398

Received: 12 March 2018; Accepted: 16 April 2018; Published: 23 April 2018

\begin{abstract}
Agriculture in Brazil is booming. Brazil has the world's second largest cattle herd and is the second largest producer of soybeans, with the production of beef, soybeans, and bioethanol forecast to increase further. Questions remain, however, about how Brazil can reconcile increases in agricultural production with protection of its remaining natural vegetation. While high hopes have been placed on the potential for intensification of low-productivity cattle ranching to spare land for other agricultural uses, cattle productivity in the Amazon biome (29\% of the Brazilian cattle herd) remains stubbornly low, and it is not clear how to realize theoretical productivity gains in practice. We provide results from six initiatives in the Brazilian Amazon, which are successfully improving cattle productivity in beef and dairy production on more than 500,000 hectares of pastureland, while supporting compliance with the Brazilian Forest Code. Spread across diverse geographies, and using a wide range of technologies, participating farms have improved productivity by $30-490 \%$. High-productivity cattle ranching requires some initial investment (R\$1300-6900/ha or US\$410-2180/ha), with average pay-back times
\end{abstract}


of 2.5-8.5 years. We conclude by reflecting on the challenges that must be overcome to scale up these young initiatives, avoid rebound increases in deforestation, and mainstream sustainable cattle ranching in the Amazon.

Keywords: livestock; Amazon; beef; dairy; sustainable intensification; land sparing

\section{Introduction}

There is growing competition for land use in Brazil. Beef, soy, and bioethanol production are forecast to grow $24 \%, 39 \%$, and $27 \%$, respectively, in the next decade [1], even as the government has committed to reforest 12 million hectares of land and reduce deforestation-with zero illegal deforestation by 2030 [2]. As pasture makes up the majority of agricultural land, high hopes are placed on the potential for increases in cattle productivity to spare land and accommodate the expansion of other land uses.

The productivity of Brazilian beef production is currently low; only one-third of its sustainable potential [3]. Brazil could in theory meet demand for beef, crops, and timber until 2040 without further conversion of natural ecosystems, by increasing cattle productivity to half of that potential [3]. Since livestock make up 37\% of Brazil's greenhouse gas emissions [4] and extensive cattle ranching has historically been associated with deforestation, cattle productivity improvements are also key to Brazil's climate goals [5]. It is hoped that cattle intensification will reduce greenhouse gas emissions through land sparing [6], increased soil carbon sequestration [7], and increased greenhouse gas intensity [8]. The Brazilian contribution to the United Nations Framework Convention on Climate Change (UNFCC, New York, NY, USA), includes commitments to reduce deforestation and increase cattle productivity through the restoration of 15 million hectares of degraded pasture [2].

In this study, we report the results from six on-the-ground initiatives which have been working to turn theory into practice by increasing the productivity of cattle ranching in the Brazilian Amazon, a region with low productivity and high potential [3]. First, we describe the current state of beef and dairy production in the Brazilian Amazon, before we summarize the results from six initiatives which are raising cattle productivity in the region. We show that there are many ways for cattle ranching production to be increased on existing pastureland; these initiatives are diverse in geography and the technologies adopted, and we summarize common successes and challenges faced by all. We then finish by reflecting on the risks and mechanisms for achieving wide-scale higher-productivity cattle ranching in the region.

\subsection{Beef Production in the Brazilian Amazon}

Nearly one third (29\%) of the Brazilian cattle herd, the second largest in the world, is found in the Amazon biome (Supplementary Material). Beef production in the region is characterized by extensive, pasture-based systems. Farmers traditionally keep zebu cattle breeds $-80 \%$ of cattle are Nelore Bos indicus [9]—and use few chemical inputs (e.g., fertilizers) and little active pasture management, leading to gradual soil degradation and loss of productivity $[10,11]$. By some estimates, $40 \%$ of pastures are in a moderate or advanced state of degradation [12], and cattle stocking rates are well below their potential [3], with little increase seen since the early 2000s [13]. These systems are typically only marginally profitable [14].

The cycle of pasture degradation and low profitability has meant that cattle ranching has historically been associated with deforestation; pasture makes up $60 \%$ of deforested land in the Legal Amazon region [15]. Recently, beef production and deforestation have uncoupled (Figure 1) and there is growing acknowledgement of the complex mix of drivers underlying deforestation. From the mid-2000s onwards, deforestation fell $70 \%$ through a combination of improvements in enforcement on private land [16], expansion of protected areas [17], market-initiatives [18], and an economic 
slowdown [19]. As deforestation again creeps upwards [20], debate continues about the relative importance of beef production, land speculation, and the rapid expansion of cropland as underlying drivers of deforestation in the Amazon [21-24].
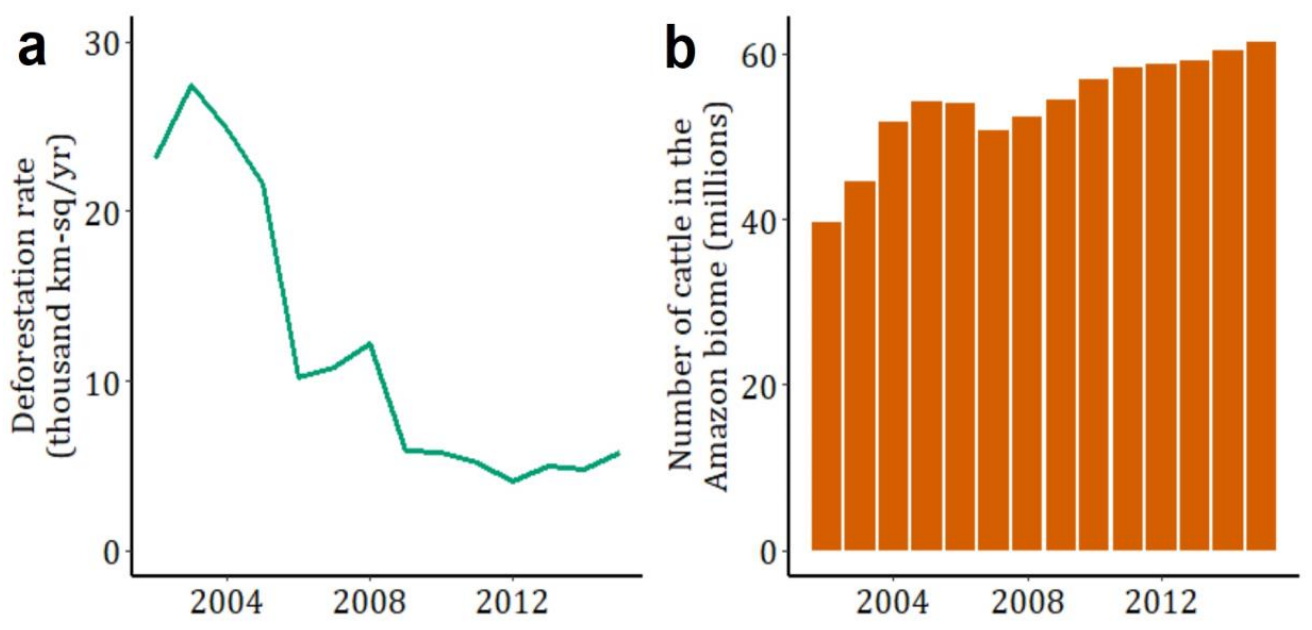

Figure 1. (a) Deforestation fell 70\% from the mid-2000s onwards; (b) even as the cattle herd in the Amazon biome continued to grow. Data from: [25,26].

Finally, Amazonian beef is becoming increasingly integrated into the global economy. Improved animal health control, such as expanding the zone of eradication of foot-and-mouth disease, has facilitated a growth in exports [27]. While most beef from the Legal Amazon region is still consumed domestically, exports have more than doubled from $<5 \%$ of production in early 2000 s to $13.5-17.4 \%$ of production by 2011 (Figure S1, Supplementary Material).

\subsection{Dairy Production in the Brazilian Amazon}

Dairy production in the Amazon is a smaller scale operation than beef ranching. Dairy cattle make up only $3.9 \%$ of all cattle in the Amazon biome [25], which is responsible for $6.3-8.7 \%$ of Brazilian milk production [25]. Dairy farming is dominated by family farms (Figure 2), producing milk for subsistence or the local market. These farms have up to 70 cattle per farm, with low use of chemical inputs and a strong reliance on family labor $[28,29]$. Milk production is pasture-based, with some farms providing supplementary feed (e.g., sugar cane silage or concentrates) in the dry season or at the milking parlor.

Dairy productivity is therefore low and can be improved. Most dairy cattle are dual-purpose zebu breeds, though the use of dairy breeds and cross-breeds is increasing, for example, the number of registered Gir cattle (a specialized dairy breed) increased 70\% (to more than 300,000 cattle) from 2007-2012 [30], though they still make up only a small proportion of the 22 million milked cows in the country [25]. Amazon municipalities have a median productivity of $689 \mathrm{~L} / \mathrm{cow} / \mathrm{yr}$, which is lower than the median for the rest of Brazil (1224 L/cow/yr), and lags behind other international milk producers, such as New Zealand and the European Union, which produce 3500-4200 and 4000-8000 L/cow/yr, respectively $[25,31,32]$. 


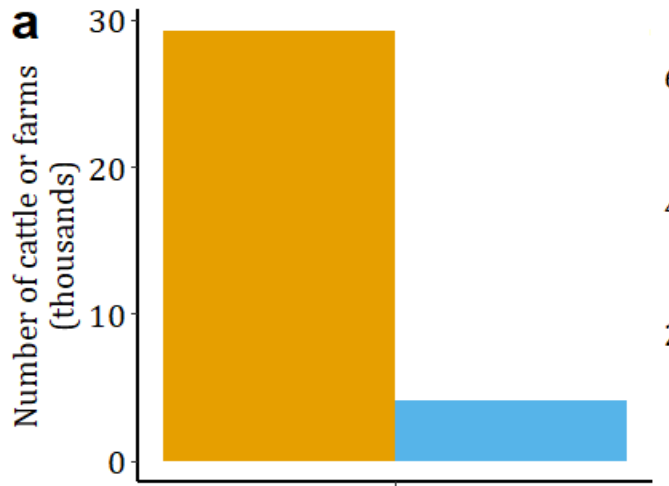

Number of dairy farms

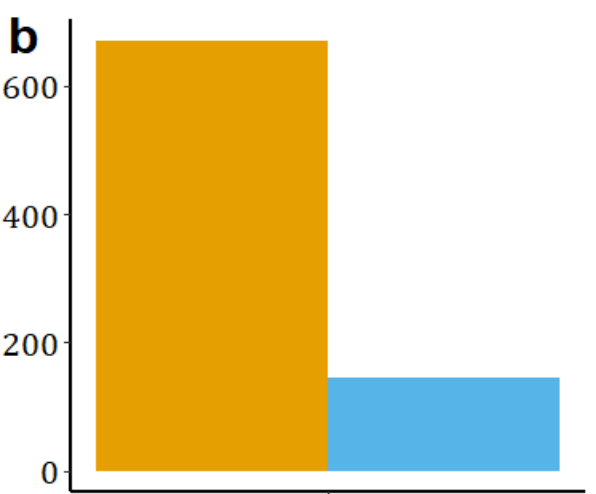

Number of milked cattle

Family farms Non-family farms

Figure 2. Dairy farming is dominated by family farms, both in terms of (a) the number of properties, and (b) number of dairy cattle. Data from: [33]. Family farming in Brazil is legally defined by a maximum farm size (ranging from 20-440 ha, dependent on the region), the number of permanent employees, and the proportion of non-agricultural income.

\section{Materials and Methods}

A questionnaire about the financial and production performance of sustainable cattle ranching initiatives (available in the Supplementary Material) was shared with the representatives of four organizations (The Nature Conservancy, Instituto Centro da Vida, Embrapa, and Idesam) who attended a conference on sustainable cattle ranching initiatives in Rio de Janeiro in September 2015. To increase our sample size, a further three initiatives operating in the Amazon region were then contacted (either directly or through the Brazilian Roundtable for Sustainable Beef, Portuguese acronym, GTPS); one of which (Florestas de Valor) provided sufficient data to participate. In total, six initiatives (led by five organizations) participated, as outlined in Table 1.

Two versions of the survey were circulated, one for beef and one for dairy intensification initiatives, structured as follows. Questions were grouped into eight sections on the (i) overview of the project (name of the initiative, and institutions involved); (ii) characteristics of the initiative (the number and types of farm participating, number of cattle and area of pasture intensified, and the year the initiative began); (iii) details of the package of technologies implemented on participating farms (farm and pasture management, forage species, use of supplementary feed, etc.); (iv) the costs involved in the implementation of improved farm management; (v) the costs involved in maintenance of improved pasture; (vi) the productivity achieved on the farm, in terms of stocking rates (animal units/ha, where one animal unit is equivalent to a $450 \mathrm{~kg} \mathrm{cow}$ ), beef production (in arroba/hectare/yr, where one arroba, abbreviated as "@", is a common Brazilian livestock unit, equivalent to $15 \mathrm{~kg}$ of carcass deadweight), or milk production (liters of milk per cow and per hectare per year); (vii) details of other measures of performance (e.g., environmental compliance, greenhouse gas emissions); and (viii) details of how farmers were recruited to each initiative and the respondent's reflections on the barriers and opportunities for improved cattle ranching.

The surveys were completed by project managers and field technicians for each initiative, who are co-authors of this review. Where survey responses were not clear, they were clarified via email by the first author. Survey data was complemented with published results from initiatives where available (e.g., [34-41], and all authors provided substantial revision of the manuscript text to ensure it accurately describes each intervention. 
Table 1. Characteristics of the cattle intensification initiatives surveyed.

\begin{tabular}{|c|c|c|c|c|c|c|c|c|c|c|}
\hline Name of Initiative & $\begin{array}{c}\text { Lead } \\
\text { Organization }\end{array}$ & Location & $\begin{array}{l}\text { Beef } \\
\text { or Dairy }\end{array}$ & $\begin{array}{c}\text { Most Important } \\
\text { Management Features }\end{array}$ & $\begin{array}{c}\text { Year } \\
\text { Project Started }\end{array}$ & $\begin{array}{l}\text { Number } \\
\text { of Farms }\end{array}$ & $\begin{array}{l}\text { Hectares of } \\
\text { Land under } \\
\text { Intensification }\end{array}$ & $\begin{array}{l}\text { Number } \\
\text { of Cattle }\end{array}$ & $\begin{array}{c}\text { Mean Farm } \\
\text { Size, Hectares } \\
\text { (Range) }\end{array}$ & $\begin{array}{c}\text { Forest Code } \\
\text { Compliance } \\
\text { Required? }\end{array}$ \\
\hline \multirow{2}{*}{$\begin{array}{l}\text { Intensification of beef } \\
\text { cattle production systems } \\
\text { with the use of mixed } \\
\text { grass-legume pastures } \\
\text { in Acre }\end{array}$} & \multirow{2}{*}{ Embrapa } & \multirow{2}{*}{ State of Acre } & \multirow{2}{*}{ Beef } & \multirow{2}{*}{$\begin{array}{l}\text { Vegetative planting of } \\
\text { mixed legume-grass } \\
\text { pastures, persistent legume } \\
\text { supply of symbiotically } \\
\text { fixed nitrogen }\end{array}$} & $\begin{array}{l}\text { Pueraria } \\
\text { phaseoloides } \\
\text { introduced } \\
\text { in 1976; }\end{array}$ & $5400^{\mathrm{a}}$ & $480,000^{\mathrm{a}}$ & \multirow{2}{*}{$\begin{array}{l}\text { No data } \\
\text { available }\end{array}$} & \multirow{2}{*}{$\begin{array}{l}\text { No data } \\
\text { available }\end{array}$} & \multirow[t]{2}{*}{ NA } \\
\hline & & & & & $\begin{array}{l}\text { Arachis pintoi } \\
\text { introduced } \\
\text { in } 1999\end{array}$ & 2000 & 137,600 & & & \\
\hline Novo Campo Program & ICV & $\begin{array}{c}\text { Alta Floresta, } \\
\text { Nova Canaã do } \\
\text { Norte, Paranaíta e } \\
\text { Cotriguaçu (MT) } \\
\end{array}$ & Beef & $\begin{array}{l}\text { Pasture rotation, pasture } \\
\text { fertilization, application } \\
\text { of GAP }\end{array}$ & 2012 & 23 & 14,300 & 23,800 & $200(30-900)$ & Yes \\
\hline Do Campo à Mesa & $\mathrm{TNC}$ & $\begin{array}{l}\text { São Félix do } \\
\text { Xingu (PA) }\end{array}$ & Beef & $\begin{array}{l}\text { Pasture rotation, pasture } \\
\text { fertilization, application } \\
\text { of GAP }\end{array}$ & 2013 & 13 & 20,208 & 34,043 & $\begin{array}{c}3077 \\
(100-6900)\end{array}$ & Yes \\
\hline $\begin{array}{l}\text { Silvopastoral system with } \\
\text { rotational grazing for beef }\end{array}$ & Idesam & Apuí (AM) & Beef & $\begin{array}{l}\text { Pasture rotation, } \\
\text { agroforestry with timber } \\
\text { and leguminous trees, } \\
\text { improved book-keeping }\end{array}$ & 2011 & 10 & 236 & $566^{\mathrm{b}}$ & $570(53-3020)$ & Yes \\
\hline $\begin{array}{l}\text { Silvopastoral system with } \\
\text { rotational grazing } \\
\text { fo dairy }\end{array}$ & Idesam & $\begin{array}{l}\text { Apuí, Manicoré, } \\
\text { Novo } \\
\text { Aripuanã (AM) }\end{array}$ & Dairy & $\begin{array}{c}\text { Pasture rotation, } \\
\text { agroforestry with } \\
\text { leguminous trees, } \\
\text { improved book-keeping, } \\
\text { and drinking water system }\end{array}$ & 2014 & 11 & 95 & $332^{b}$ & $188(83-340)$ & Yes \\
\hline Florestas de Valor & IMAFLORA & $\begin{array}{l}\text { São Félix do } \\
\text { Xingu (PA) }\end{array}$ & Dairy & $\begin{array}{l}\text { Rotational grazing, } \\
\text { leguminous trees lining } \\
\text { fenced plots }\end{array}$ & 2015 & 6 & 50 & 145 & $83(25-200)$ & Yes \\
\hline
\end{tabular}

a Figures from 2004, the last year that production practices in the region were surveyed; ${ }^{\mathrm{b}}$ Estimate based on mean stocking rates and pasture area of farms. Ranges are listed in brackets, where provided. State abbreviations: Embrapa = the Brazilian Corporation for Agriculture Research; ICV = Instituto Centra da Vida; TNC = The Nature Conservancy; Idesam = Institute

for Conservation and Sustainable Development of the Amazon; IMAFLORA = Institute of Forestry and Agricultural Management and Certification; MT = Mato Grosso; AM = Amazonas;

PA = Pará. 


\section{Results}

We provide results from six sustainable cattle intensification initiatives in the Amazon biome, four working with beef producers and two with dairy producers (Table 1). While one of these initiatives was launched in 1976 and introduced legume pasture technologies which have since been adopted on more than 5000 farms, the remaining initiatives are more recent (established post-2011). These latter initiatives operate on 63 farms raising 59,000 cattle on 35,000 hectares of pasture in three states (Figure 3). The technologies deployed are diverse, ranging from relatively low-input leguminous systems to more input-intensive rotational grazing systems.

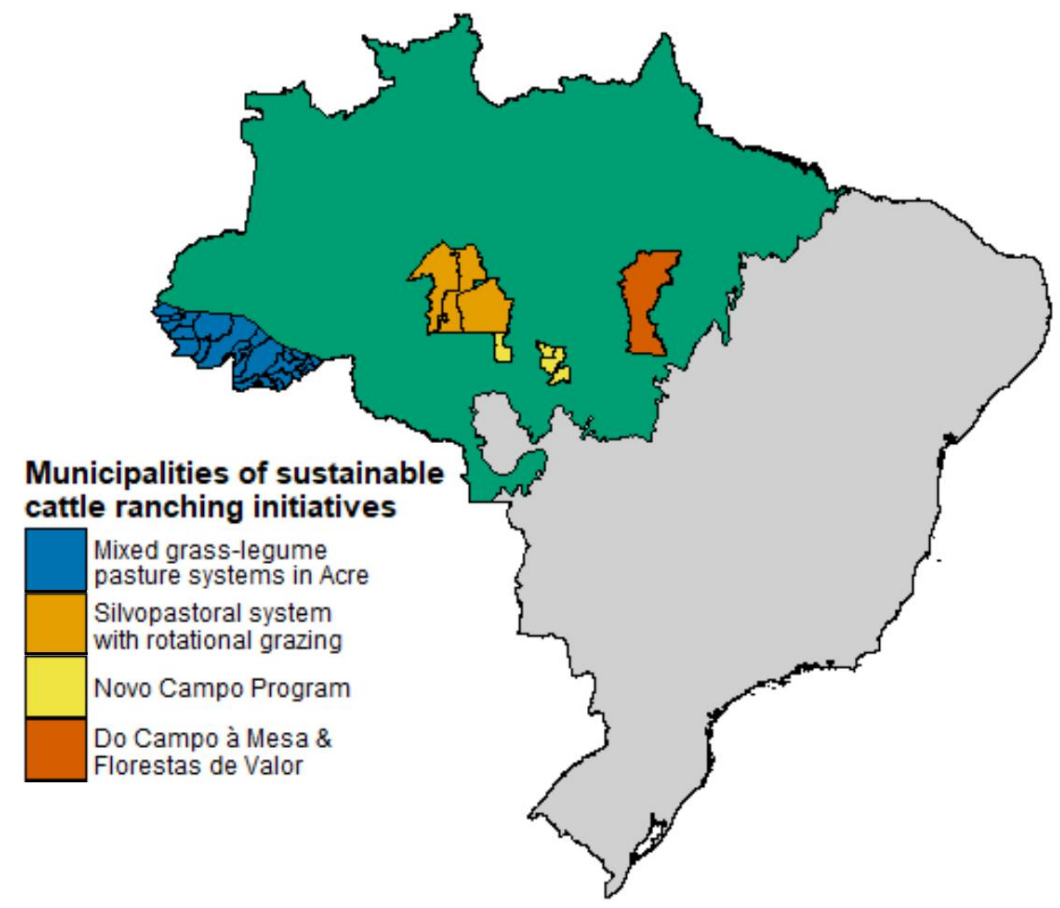

Figure 3. Map of Brazil, with the Amazon biome colored in green, and the municipalities where the sustainable cattle initiatives reported in this article are present shown in other colors.

Each initiative has achieved higher farm productivity, boosting meat production per hectare by $30-270 \%$ and dairy production per hectare up to $490 \%$ (Tables 2 and 3 ). While the use of higher-yielding technologies is profitable in most cases, it requires initial investment to improve farm productivity, with payback times ranging from 1.5-12 years. The specifics and results of each initiative are described in more detail below.

\subsection{Beef Case Study \#1-Intensification of Cattle Production Systems with the Use of Mixed Grass-Legume} Pastures in Acre

In 1976, the Brazilian Corporation for Agriculture Research (Embrapa, Brasília, Brazil) established the Program for Reclamation, Improvement and Management of Pastures in the Brazilian Amazon (PROPASTO) which included a series of on-farm experiments to promote the adoption of mixed legume pastures in the state of Acre [40]. A number of cultivars were launched, of which one legume, Pueraria phaseoloides (tropical kudzu), was the first to be adopted at scale. By 2004, tropical kudzu was present in over $30 \%$ (480,000 ha) of the total pasture area in Acre and has been successfully planted in combination with a variety of grass species (Table S1, Supplementary Material) [40]. 
Table 2. Productivity and profitability of initiatives increasing productivity of beef production. Ranges listed in brackets, where provided.

\begin{tabular}{|c|c|c|c|c|c|c|c|c|c|c|c|}
\hline Name of Initiative & & $\begin{array}{c}\text { Baseline } \\
\text { Stocking Rate } \\
\text { (AU/ha) }\end{array}$ & $\begin{array}{l}\text { Stocking Rate } \\
\text { (AU/ha) }\end{array}$ & $\begin{array}{l}\text { Increase in } \\
\text { Stocking } \\
\text { Rate over } \\
\text { Baseline }\end{array}$ & $\begin{array}{l}\text { Baseline } \\
\text { Productivity } \\
\text { (@/ha/yr) }\end{array}$ & $\begin{array}{l}\text { Productivity } \\
\text { (@/ha/yr) }\end{array}$ & $\begin{array}{c}\text { Average } \\
\text { Increase in } \\
\text { Productivity }\end{array}$ & $\begin{array}{l}\text { Years to Break } \\
\text { Even on } \\
\text { Investment }\end{array}$ & $\begin{array}{c}\text { Years to } \\
\text { Achieve Max } \\
\text { Productivity }\end{array}$ & $\begin{array}{c}\text { Typical Profit/ } \\
\text { Hectare/Year (R\$) }\end{array}$ & $\begin{array}{l}\text { Additional } \\
\text { References }\end{array}$ \\
\hline \multirow{2}{*}{$\begin{array}{l}\text { Intensification of } \\
\text { beef cattle } \\
\text { production systems } \\
\text { with the use of } \\
\text { mixed grass-legume } \\
\text { pastures in Acre }\end{array}$} & $\begin{array}{c}\text { Mixed } \\
\text { grass-Pueraria } \\
\text { phaseoloides } \\
\text { pastures }\end{array}$ & \multirow{2}{*}{$1^{*}$} & $1.5(1-2)$ & $1.5 x$ & \multirow{2}{*}{$8(4-10) *$} & $\begin{array}{c}10 \\
(4.9-12.5)\end{array}$ & $1.3 x$ & $3(2-4)$ & $2(1.5-3)$ & $149-271$ & \multirow{2}{*}[39,42-44]{} \\
\hline & $\begin{array}{c}\text { Mixed } \\
\text { grass-Arachis } \\
\text { pintoi pastures }\end{array}$ & & $2.2(1.5-3.59)$ & $2.2 x$ & & $12(13-35)$ & $1.5 x$ & $4(3-5)$ & $3(2-5)$ & $296-381$ & \\
\hline $\begin{array}{c}\text { Novo } \\
\text { Campo Program }\end{array}$ & & $1.22 *$ & $2.8(1.5-3.5)$ & $2.3 x$ & $4.7^{*}$ & $10.8(7-27)$ & $2.1 x$ & $2.5(1.5-4)$ & $\begin{array}{l}\text { Data not } \\
\text { provided }\end{array}$ & 602 (173-1140) & {$[4,38]$} \\
\hline Do Campo à Mesa & & $0.87(0-2.81)$ & $1.06(0.27-3.05)$ & $1.2 \mathrm{x}$ & $\begin{array}{c}4.5 \\
(0.9-10.5)\end{array}$ & $\begin{array}{c}5.87 \\
(1.42-19.2)\end{array}$ & $1.3 x$ & $8.5(7-12)$ & $\sim 6$ & $432(-546-1103)$ & [37] \\
\hline $\begin{array}{l}\text { Silvopastoral System } \\
\text { with Rotational } \\
\text { Grazing for Beef }\end{array}$ & & $0.60(0.45-0.7)$ & $2.4(2.0-2.7)$ & $4.0 \mathrm{x}$ & $5.5(4-7)$ & $15(12-20)$ & $2.7 x$ & $5(4-6)$ & 5 & $\sim 263$ & - \\
\hline
\end{tabular}

$\mathrm{AU}=$ animal stocking unit, equivalent to a $450 \mathrm{~kg}$ cow; $@=15 \mathrm{~kg}$ of carcass (deadweight). * productivity data are not available from participating farms pre-adoption, and so the baseline data are estimates of the regional average productivity without the adopted technology. Estimates of profitability do not include revenues from farm activities not directly related with cattle production (e.g., sale of timber trees or crops), and costs are representative of the interventions made on participating farms (they do not, for example, consider the cost of acquiring land or purchasing cattle, as participating farms used on-farm resources for intensification). 
Embrapa began by introducing mixed legume pastures on properties belonging to three farmers, who were identified as innovators [40]. Knowledge of these novel technologies then spread through word of mouth and trained agricultural extension officers. Legumes were promoted because of their ability to fix nitrogen, which reduces pasture maintenance costs and produces a protein-rich sward (Figure 4); a pasture sown with 20-45\% Tropical kudzu produces nitrogen equivalent to approximately 60-120 kg of N/ha/yr [42]. Grass-legume associations cost between R $\$ 1350-2000 /$ hectare to implement, and around $\mathrm{R} \$ 100 / \mathrm{ha} / \mathrm{yr}$ to maintain (Table 4) and are therefore a relatively low-cost intensification technology for pasture restoration and intensification. Tropical kudzu pastures produce modest productivity improvements, supporting 1.5 animal units/ha and producing 4.9-12.5 @/ha/yr (Table 2).

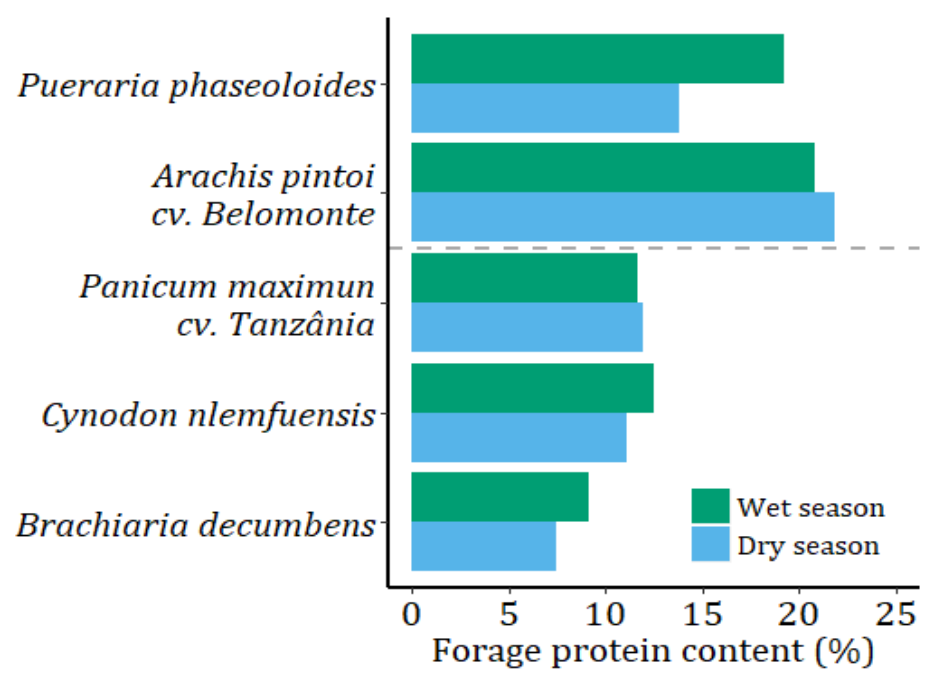

Figure 4. Leguminous pasture plants (above the dashed line) have higher protein content than conventional grasses (below dashed line). Source: [45].

Since a peak in the early 2000s, the popularity of Tropical kudzu has declined as it showed poor compatibility with some of the newer grass species being planted by farmers, such as African stargrass (Cynodon nlemfuensis), and also failed to persist when managed in more intensive production systems using mixed pastures with other grasses and rotational grazing at stocking rates above 1.5 animal units per hectare. For these situations, Embrapa promoted forage peanut cultivar Belomonte (Arachis pintoi) [41].

This new cultivar was released in 1999 in Bahia, Brazil. First planted by a single farmer in Acre in 2000, in April 200120 farmers planted this legume together with a variety of grasses (Figure 5 and Table S1, Supplementary Material). Adoption was rapid. By March 2004, close to 1000 small, medium and large farmers of Acre had already introduced forage peanut into 65,000 ha of pasture [41], and by 2015 forage peanut was planted across 2000 farms and 137,000 ha in Acre [39], approximately nine percent of the state's pasture area [46].

Forage peanut can be either planted along with other grasses during pasture restoration (i.e., replanting of a degraded pasture), or introduced onto existent pasture during the rainy season. Since forage peanut cultivar Belomonte does not produce seeds (it instead reproduces vegetatively), it must be planted using stolon cuttings. Farmers usually set aside an area $(<1 \mathrm{ha})$ where forage peanut grows in dense stands (i.e., without competing grasses), from which the vegetative stolons are then harvested for planting in pasture. Embrapa have successfully developed a number of techniques for establishing grass-legume pastures using vegetative propagation of forage peanut and stoloniferous grasses, depending on the farmer's technology level, ranging from semi- to fully-mechanized and either conventional or no-till agriculture [34]. African stargrass-forage peanut pastures managed under rotational grazing can support up to 3 animal units/ha (Table 2), producing Nelore $\times$ Angus crossbred 
steers ready for slaughter within 24 months (Table S2, Supplementary Material), compared with the $36+$ months typical of extensive systems [41]. These productivity improvements also improve the farm bottom line, increasing profitability from around $\mathrm{R} \$ 41.10 / \mathrm{ha} / \mathrm{yr}$ in traditional systems up to $\mathrm{R} \$ 381.28 /$ ha $/ \mathrm{yr}$ (Table 2).

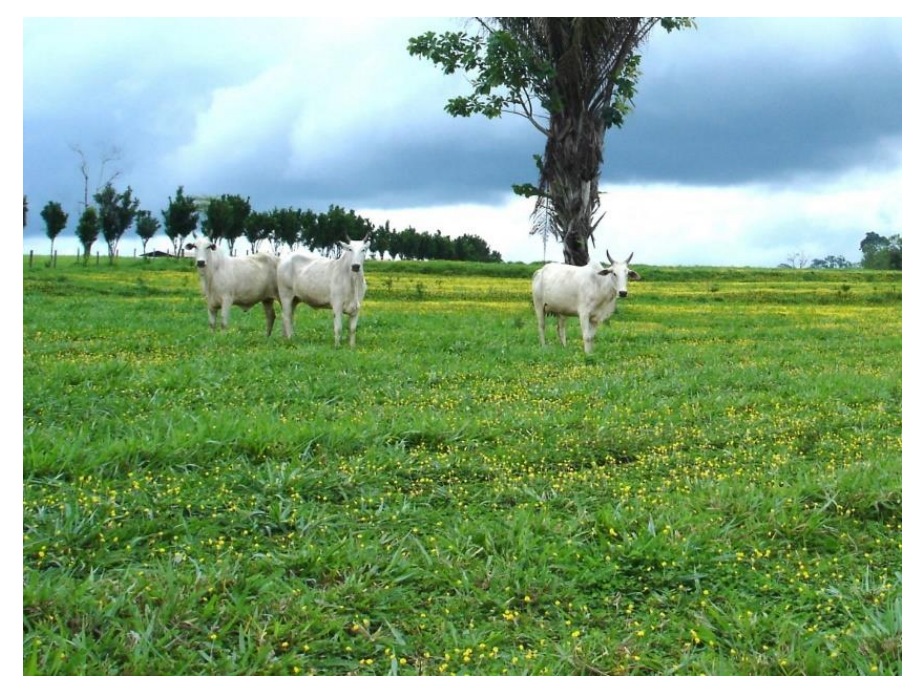

Figure 5. Nelore cattle (Bos indicus) grazing mixed pasture: forage peanut (Arachis pintoi cv. Belomonte) (the yellow flowering plants) with Brachiara spp.

Grass-legume pastures can mitigate greenhouse gas emissions by substituting for fossil-fuel dependent nitrogen fertilizers, by reducing cattle slaughter ages [42,47], and by increasing soil carbon sequestration [48]. Additionally, Costa et al. [49] reported that mixed pastures of Brachiaria humidicola and forage peanut cv. Mandobi in Acre had 24\% lower $\mathrm{N}_{2} \mathrm{O}$ emission $\left(2.38 \mathrm{~kg} \mathrm{~N} \mathrm{ha}^{-1} \mathrm{yr}^{-1}\right)$ than pure pasture of the same grass $\left(3.13 \mathrm{~kg} \mathrm{~N} \mathrm{ha}^{-1} \mathrm{yr}^{-1}\right)$ and similar emissions to native forest $\left(2.47 \mathrm{~kg} \mathrm{~N} \mathrm{ha}^{-1} \mathrm{yr}^{-1}\right)$.

\subsection{Beef Case Study \#2-Novo Campo Program}

The Novo Campo Program ("New Field" Program in English) has involved 23 farms in the Alta Floresta region of Mato Grosso since 2012. Led by the Instituto Centro de Vida (ICV), with collaboration with stakeholders from across the cattle supply chain (see Table 4 for a complete list of participating organizations), cattle productivity has been increased through a package of farm management changes. These include the introduction of pasture rotation, the adoption of so called "good agricultural practices" (GAP), correction of soil imbalances (e.g., by liming), pasture fertilization, and improved farm record keeping. The GAP is a voluntary set of "gold-standard" guidelines for sustainable production adopted across Brazil, which includes a check-list of 125 points of guidance across 11 areas of farm management, spanning farm economic management, social and environmental responsibilities, to pasture and herd management [50].

Together, these interventions have improved farm productivity and profitability, and reduced greenhouse gas emissions (Figure 6 ). Beef production per hectare has increased from $\sim 4.7$ (the regional average) to 7-24@/ha/yr, which has reduced the cost of production per arroba on intensified farms by one third (R\$66.33/@ vs. R\$95.80/@) [38]. Profit increased from less than $\mathrm{R} \$ 100 /$ ha/yr to more than $\mathrm{R} \$ 600 / \mathrm{ha} / \mathrm{yr}$ of pasture (Table 2). These yield-raising technologies require an initial investment of $\mathrm{R} \$ 1500-4000 / \mathrm{ha}$, depending on the initial pasture condition, though these up-front costs are paid off after an average of 2.5 years (Table 2). 
Table 3. Productivity of dairy intensification initiatives surveyed. Ranges are listed in brackets, where provided.

\begin{tabular}{|c|c|c|c|c|c|c|c|c|c|c|c|c|}
\hline Name of Initiative & $\begin{array}{c}\text { Baseline } \\
\text { Stocking } \\
\text { Rate (AU/ha) }\end{array}$ & $\begin{array}{l}\text { Stocking } \\
\text { Rate } \\
\text { (AU/ha) }\end{array}$ & $\begin{array}{c}\text { Increase in } \\
\text { Stocking } \\
\text { Rate over } \\
\text { Baseline }\end{array}$ & $\begin{array}{c}\text { Baseline } \\
\text { Productivity } \\
\text { (L/ha/yr) }\end{array}$ & $\begin{array}{l}\text { Productivity } \\
\text { (L/ha/yr) }\end{array}$ & $\begin{array}{c}\text { Increase in } \\
\text { Productivity } \\
\text { Over } \\
\text { Baseline }\end{array}$ & $\begin{array}{c}\text { Baseline } \\
\text { Productivity } \\
\text { (L/cow/yr) }\end{array}$ & $\begin{array}{l}\text { Productivity } \\
\text { (L/cow/yr) }\end{array}$ & $\begin{array}{c}\text { Increase in } \\
\text { Productivity } \\
\text { over Baseline }\end{array}$ & $\begin{array}{l}\text { Years to Break } \\
\text { Even on } \\
\text { Investment }\end{array}$ & $\begin{array}{c}\text { Years to } \\
\text { Achieve Max } \\
\text { Productivity }\end{array}$ & $\begin{array}{c}\text { Typical } \\
\text { profit/ha/yr (R\$) }\end{array}$ \\
\hline $\begin{array}{l}\text { Silvopastoral System } \\
\text { with Rotational } \\
\text { Grazing for Dairy }\end{array}$ & $0.75(0.5-1.08)$ & $\begin{array}{c}3.5 \\
(2.4-6.3)\end{array}$ & $4.7 x$ & $\sim 1192$ & $\begin{array}{c}5794 \\
(2969-9037)\end{array}$ & $4.9 \mathrm{x}$ & $\begin{array}{c}1551 \\
(760-1825)\end{array}$ & $\begin{array}{c}1954 \\
(1642-2482)\end{array}$ & $1.26 \mathrm{x}$ & $2.6(1.8-6.8)$ & $6(5-7)$ & 4425 (2176-8092) \\
\hline Florestas de Valor & $1.1(0.9-1.2)^{*}$ & $\begin{array}{c}3.1 \\
(2.5-3.7)\end{array}$ & $2.8 x$ & $\begin{array}{l}\text { Data not } \\
\text { provided }\end{array}$ & $\sim 3190$ & $\begin{array}{l}\text { Data not } \\
\text { provided }\end{array}$ & $\sim 760$ & $\sim 1100$ & $1.4 \mathrm{x}$ & $4(3-5)$ & $3(2-4)$ & $\begin{array}{l}\text { Data not } \\
\text { provided }\end{array}$ \\
\hline
\end{tabular}

* productivity data are not available from participating farms pre-adoption, and so the baseline data are estimates of the regional average productivity without the adopted technology.

Table 4. Typical costs involved in each intensification initiative. Degraded pastures are pastures with declining pasture fertility; their restoration often requires soil correction, ploughing, and reseeding of grasses, whereas soil correction and ploughing may not be required for conventional pasture improvement. Ranges are listed in brackets, where provided.

\begin{tabular}{|c|c|c|c|c|c|c|}
\hline \multirow[b]{2}{*}{ Name of Initiative } & \multirow[b]{2}{*}{ Organizations Involved } & \multirow[b]{2}{*}{ Ranching Systems } & \multicolumn{2}{|c|}{ Cost of Intensification (R\$/ha) } & \multirow{2}{*}{$\begin{array}{l}\text { Cost of Pasture } \\
\text { Maintenance } \\
\text { (R\$/ha/yr) }\end{array}$} & \multirow{2}{*}{$\begin{array}{l}\text { Cost of Technical } \\
\text { Assistance } \\
\text { (R\$/property/yr) }\end{array}$} \\
\hline & & & $\begin{array}{c}\text { Improvement of } \\
\text { Degraded Pasture }\end{array}$ & $\begin{array}{c}\text { Improvement of } \\
\text { Conventional Pasture }\end{array}$ & & \\
\hline $\begin{array}{l}\text { Intensification of beef cattle } \\
\text { production systems with the use } \\
\text { of mixed grass-legume pastures } \\
\text { in Acre }\end{array}$ & $\begin{array}{l}\text { Embrapa Acre, Federação de Agricultura do Estado do } \\
\text { AcreFundo de Desenvolvimento da Pecuária do Estado do } \\
\text { Acre, \& Associação para o Fomento à Pesquisa de } \\
\text { Melhoramento de Forrageiras }\end{array}$ & $\begin{array}{l}\text { Cow-calf, calf raising \& } \\
\text { fattening, full cycle }\end{array}$ & \multicolumn{2}{|c|}{$\begin{array}{l}\text { Semi-mechanized conventional planting: } 2011 . \\
\text { Mechanized conventional planting: 1461-1920. } \\
\text { Mechanized no-till planting: 1347-1806 }\end{array}$} & $\sim 100$ & Data not collected \\
\hline Novo Campo Program & $\begin{array}{l}\text { ICV, International Institute for Sustainability (IIS), Embrapa, } \\
\text { Solidariedad, Sindicatos Rurais de Alta Floresta e } \\
\text { Cotriguaçu, JBS, McDonalds, Arcos Dourados, IMAFLORA, } \\
\text { Althelia Ecosphere, Terras, GTPS, Fundo Vale, Norad, \& the } \\
\text { Moore Foundation }\end{array}$ & Calf raising \& fattening & $3500(3000-4000)$ & $2000(1500-2000)$ & $1800(1500-2000)$ & $8000(6000-12000)$ \\
\hline Do Campo à Mesa & TNC, Marfrig, Walmart, GTPS, \& the Moore foundation & Calf raising \& fattening & $1890(1750-1897)$ & 1468 (1318-1571) & $\sim 680$ & Data not collected \\
\hline $\begin{array}{l}\text { Silvopastoral System with } \\
\text { Rotational Grazing for Beef }\end{array}$ & $\begin{array}{l}\text { Idesam, Centro para Investigación en Sistemas Sostenibles } \\
\text { de Producción Agropecuária (CIPAV), Via Verde Consultoria } \\
\text { Agropecuária, Fundo Vale, \& Viveiro Santa Luzia }\end{array}$ & $\begin{array}{l}\text { Cow-calf, calf raising } \\
\quad \& \text { fattening }\end{array}$ & $2666(2412-3021)$ & $\begin{array}{c}\text { All farms had } \\
\text { degraded pasture }\end{array}$ & $\sim 216.25$ & $\sim 5480$ \\
\hline $\begin{array}{c}\text { Silvopastoral System with } \\
\text { Rotational Grazing for Dairy }\end{array}$ & $\begin{array}{l}\text { Idesam, CIPAV, \& Via Verde Consultoria Agropecuária, } \\
\text { Fundo Vale, \& Viveiro Santa Luzia }\end{array}$ & Cow-calf & $5355(4900-6866)$ & $\begin{array}{c}\text { All farms had } \\
\text { degraded pasture }\end{array}$ & $\sim 275$ & $\sim 5480$ \\
\hline Florestas de Valor & $\begin{array}{c}\text { IMAFLORA, CAMPPAX (Cooperativa Alternativa Mista do } \\
\text { Alto Xingu), ADAFAX (Associação Desenvolvimento da } \\
\text { Agricultura Familiar do Alto Xingu), CFA (Casa Familiar } \\
\text { Rural de São Felix do Xingu), Petrobras, Fundo Vale, \& } \\
\text { Fundo Amazônia }\end{array}$ & Cow-calf & $\sim 2500$ & $\begin{array}{c}\text { All farms had } \\
\text { degraded pasture }\end{array}$ & $2000(1200-2560)$ & $2500(2000-3000)$ \\
\hline
\end{tabular}


By improving animal growth rates and so achieving slaughter weight in fewer days, farmers reduce emissions from enteric fermentation across the animal's lifetime (enteric fermentation contributes $67-83 \%$ of emissions, excluding land use change-a topic we return to in Section 4 [8,51,52]). This is seen from the experience on Novo Campo Program farms. Emissions have been reduced by $36-59 \%$ (Figure 6), in large part through reductions in slaughter age down to 20-24 months (Table S2, Supplementary Material).

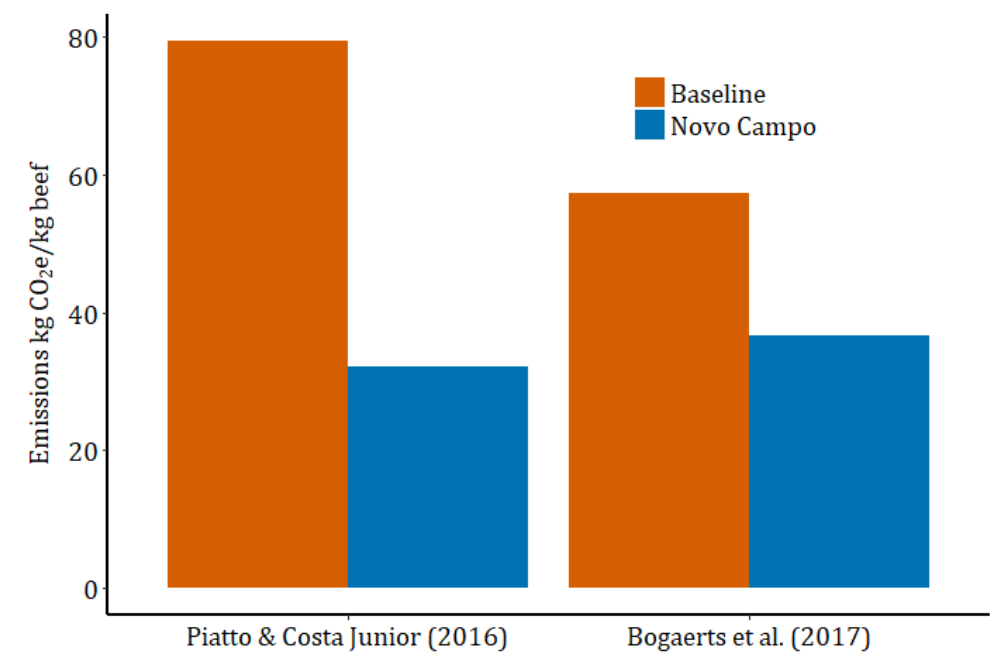

Figure 6. Two estimates for the emissions per kilogram of beef of conventional ranches and Novo Campo Program farms. Piatto and Costa Junior [53] compare emissions on pilot farms before pasture intensification (baseline), with emissions after two years of participating in the initiative. Bogaerts et al. [8] compare farms participating in the Novo Campo Program with neighboring non-participating farms. While both studies include emissions from enteric fermentation, manure management, pasture fertilization, and fossil fuels required for pasture restoration, Bogaerts et al. also include emissions from concentrate feed production, and Piatto and Costa Junior include carbon sequestration in improved pasture and soil carbon emissions from degraded pasture. No emissions from land use change are included, because no recent deforestation occurred on sampled farms.

Key changes in farm management are improved book-keeping and the introduction of rotational pasture management. Adequate book-keeping is fundamental to understanding and improving farm management processes, and yet is not done by a majority of farm managers or owners [4]. Farmers are therefore trained in the importance of recording the costs of all inputs and the quantity and value of beef produced, to allow the calculation of the income and profit per arroba of beef. Once the economic performance of the farm is established, rotational grazing is introduced.

Typically, $10-30 \%$ of the farms' pasture area is fenced off into ca. 5-hectare plots, which are targeted for pasture improvement. Pasture restoration begins with soil analysis to identify soil imbalances (e.g., pH). The pasture is then ploughed and limed (typically with $1500 \mathrm{~kg} /$ ha lime; Table S3, Supplementary Material), and the pasture is fertilized (400 kg/ha) and replanted, with Panicum maximun cv. Mombaça or Panicum maximun cv. Tanzânia grasses (Figure 7).

These fertilized plots have much higher productivity than conventionally managed pasture; in the first two years of the project, they produced $20.75 @ /$ ha/yr compared with $10.75 @ /$ ha/yr across the farm as a whole (Marcuzzo and de Lima, 2015). Cattle are moved through each fenced plot sequentially; the stocking rate and exact timing of the cattle rotation are based on the season, forage height, and planted species, manipulated to maximize cattle growth while maintaining pasture fertility. With Panicum maximun cv. Mombaça, cattle enter plots when the grass height is around $90 \mathrm{~cm}$ and are moved when it has been grazed down to around $40 \mathrm{~cm}$ (approximately every five days in the wet season, and less frequently during the dry season). 

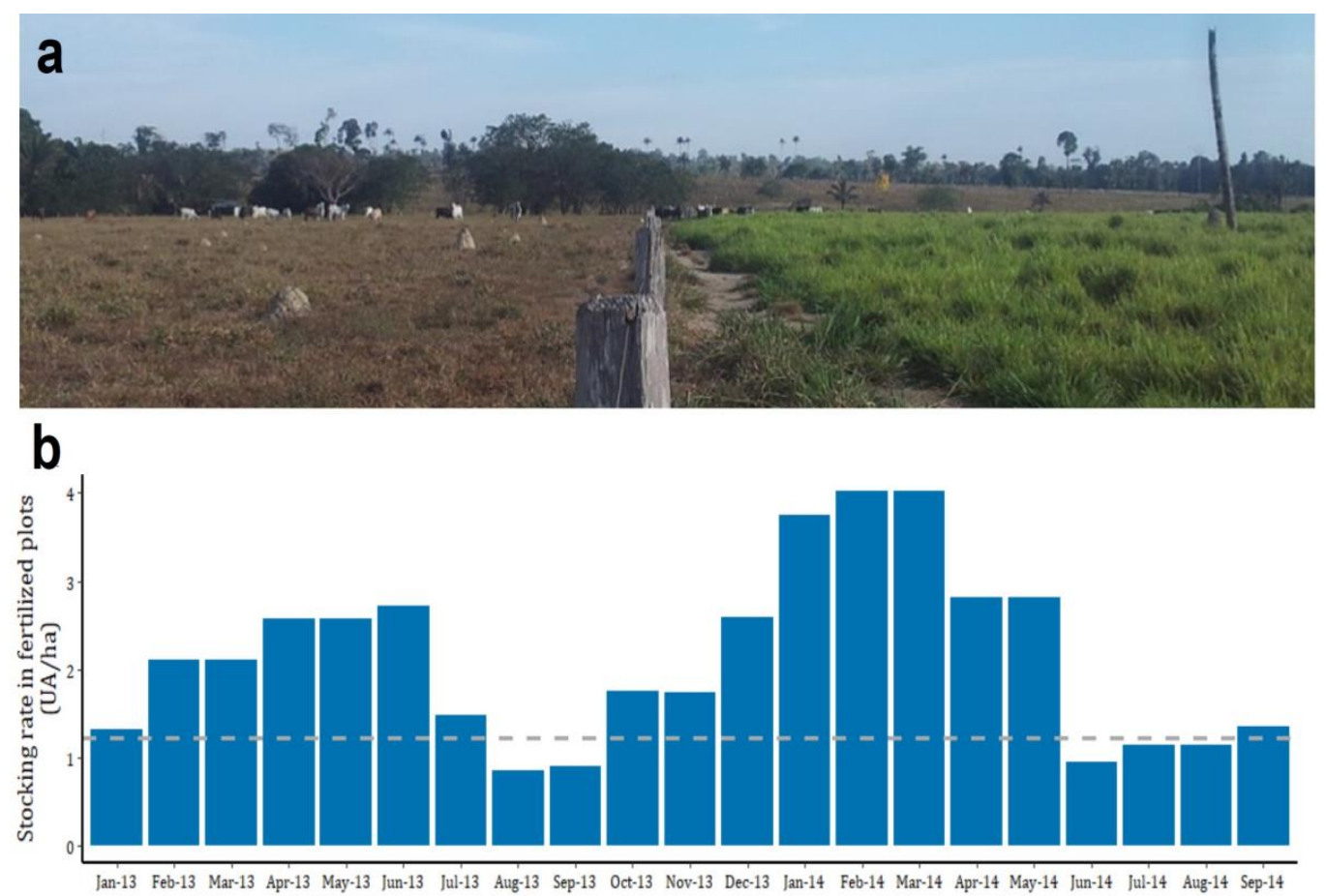

Figure 7. (a) High-yielding cattle pasture (right) on a Novo Campo Program farm, one month after replanting, compared with conventional, unreformed pasture (left); (b) Stocking rate in intensified pasture plots for the period January 2013-September 2014. The grey dashed line represents the mean stocking rate for farms in the region. Adapted from: [38].

While forage is in abundant supply in the rainy season (from approximately December-May), in the dry period, stocking rates in the intensified pasture areas are reduced (Figure 7), and supplementary feeding is necessary. Novo Campo Program farms have adopted a semi-feedlot feeding approach, where cattle are given supplementary concentrate feed in troughs in a confined area of pasture. One farm has also integrated soy and beef production to boost dry season feed availability. Soy is planted on 200 ha, which is seeded with Brachiaria spp. after the soy harvest. This additional pasture area then serves as an additional forage source during the dry period.

All Novo Campo participating farmers qualify for the GAP certificate, developed by Embrapa. The adoption of GAP requires training of farm personnel, and ultimately, approximately a $50 \%$ increase in on-farm labor. To support the dissemination of knowledge to staff on Novo Campo farms and beyond, ICV therefore linked up with a local university, UNEMAT Alta Floresta, to train an additional 40 agricultural extension officers in GAP, environmental licensing, farm financial analysis, and the use of farm management software [38].

Farms participating in the Novo Campo Program must also comply with Brazilian National Law No. 12.651, the so called 'Forest Code'. They must be registered in the rural environmental registry (Portuguese acronym CAR), cannot be blacklisted by the environmental police (IBAMA), and must have had no illegal deforestation post-2008. On joining the Novo Campo Program, many farms had degraded riparian areas, which legally must be reforested within 20 years. Properties received support from ICV in restoring these areas, with the restoration actions depending on the degradation status and location of streams. Where streams had some secondary regrowth and/or nearby forest, this might include only fencing-off streams from cattle to foster natural regeneration; where riparian areas were more degraded or isolated, they may have required direct seeding of trees, removal of grasses and the control of pests. In both cases, restoration is not cheap with costs varying from $\mathrm{R} \$ 2360 /$ ha for passive restoration, to $\mathrm{R} \$ 9654 /$ ha for active replanting [54]. 
To scale-up the results achieved in the Novo Campo Program, a commercial spin-off, PECSA, was launched in 2015. While management of the Novo Campo continues under ICV, PECSA applies the same package of technologies, in some cases intensifying more than the $30 \%$ of pasture area used in the Novo Campo Program to increase farm productivity 3-5 times above the regional average [55].

\subsection{Beef Case Study \#3 Do Campo à Mesa}

Launched in 2013, as a collaboration between The Nature Conservancy (TNC) and several partners along the beef supply chain (Table 4), the do Campo à Mesa initiative ("From Field to Table" in English) operates on 13 farms in São Félix do Xingu, Pará, to boost productivity through the establishment of rotational pasture and training in GAP. Results after one year of the project are promising; stocking rates increased $20 \%$ and beef productivity $30 \%$ (Table 2 ), with substantially greater gains expected; beef productivity is forecast to increase more than 3.5-times to 17@/ha (10-27@/ha) within 12 years of the start of the project [37].

On joining the initiative, baseline data were collected by agricultural extension officers on the herd structure (e.g., number of animals, category, age, weight), farm operating costs, and soil condition. These are complemented with remote sensing analyses of the farm's land use. Many farms had considerable areas of degraded pasture, $23 \%$ and $18 \%$ of pasture was moderately or highly-degraded, respectively [37]. To combat this, management plans were drawn up to improve $20 \%$ of the farm's pasture area each year so that after five years all pasture would be in improved condition.

Goals for stocking rates were set, aiming to gradually increase stocking rates from $0.87 \mathrm{AU} / \mathrm{ha}$ to $3.0 \mathrm{AU} / \mathrm{ha}$. To achieve this, the initiative has used pasture improvement (weeding and liming, and resowing of pasture if degraded), education of farm workers in GAP, and the establishment of rotational grazing. Livestock are also given $1.5 \mathrm{~kg} /$ head/day of protein supplementary feed in the dry season, to overcome the seasonal deficit in feed availability.

The main costs of improving farming practices come in three forms: pasture improvement and maintenance, adoption of GAP, and costs of environmental compliance; these costs vary strongly with farm size. Pasture improvement requires an initial investment of between R $\$ 1300-1900 / \mathrm{ha} / \mathrm{yr}$ (Table 4), and adoption of GAP requires not only worker education, but also improvements in infrastructure and more farm labor. After 12 years of the project, the requirement for labor is forecast to increase on average $54 \%$, with larger increases on the biggest farms [37]. On small farms labor is family-based and will be kept constant, while large farms plan to increase their number of employees three-fold. Do Campo à Mesa farms must also be compliant with the Forest Code, which also incurs substantial costs. Compulsory restoration of deforested areas added an extra $30-250 \%$ to the cost of adopting improved farm practices [37]. Taking all the costs of the transition to more sustainable farming practices together, pasture intensification and legal compliance generated better economic returns for large farms ( $>500$ ha of pasture) ([37]. Costs per hectare for the three smallest properties were on average 2.3 times higher than for other farms, and the two smallest farms, with 44 and 126 ha of pasture area, were not projected to make a profit and subsequently elected not to continue with cattle intensification. To help overcome the initial cost barrier and support the growth of the program, TNC helps farmers apply for loans from the Brazilian government's low carbon fund (the "Plano ABC", in Portuguese).

\subsection{Beef Case Study \#4_Silvopastoral System with Rotational Grazing for Beef}

In 2011, the Institute for Conservation and Sustainable Development of the Amazon (Portuguese acronym, Idesam) launched the Silvopastoral System with Rotational Grazing initiative ("Sistema Silvipastoril com Pastejo Rotacional", in Portuguese), on beef and dairy farms in Apuí, Amazonas. The initiative is working with 10 beef farms to boost productivity of smallholder beef production (results for dairy farms are listed in diary case study \#1). While the planting of trees and shrubs, involves high up-front costs (Table 4), participating beef farms have improved productivity from 4-7@/ha/yr to 12-20@/ha/yr, and profitability from $\sim \mathrm{R} \$ 130 /$ ha/yr to $\mathrm{R} \$ 260 /$ ha/yr (Table 2). 
Farm improvement begins with a visit from an agricultural extension technician, collecting baseline farm information and drawing up management plans with the farmer. To introduce rotational grazing, an area of between 20-50 hectares is intensified on each farm by restoring pasture through the application of lime, where required. This area is then divided into six plots, sown with Panicum maximum cv. Mombaça or Brachiaria brizantha, fertilized with phosphorus, and managed in a rotational system. Cattle are moved through each plot approximately every 6-7 days according to the pasture condition.

These plots are divided by double electric fences (1.5 to $2 \mathrm{~m}$ in width) protecting a line of trees planted $3 \mathrm{~m}$ apart (Figure 8). The trees are mostly native species, half of which are planted for their timber or other economic value and the other half are a mix of leguminous tree species (20-30 trees/ha), including Inga-de-metro (Inga edulis Mart.) Leucaena (Leucaena leucocephala var. cunningham) Paricá (Schizolobium amazonicum) Gliricídia (Gliricidia sepium), Jatobá (Hymenaea courbaril), and Parkia spp. Among the trees, fodder shrubs are also planted, including Tithonia diversifolia and Cratília (Cratylia argentea). The principal benefits of planting leguminous trees and fodder shrubs in pasture are that the leaves provide a high-protein feed [56], increased shade which can reduce heat stress in cattle [57], and nitrogen-fixation which boosts grass growth and can improve soil condition [58].
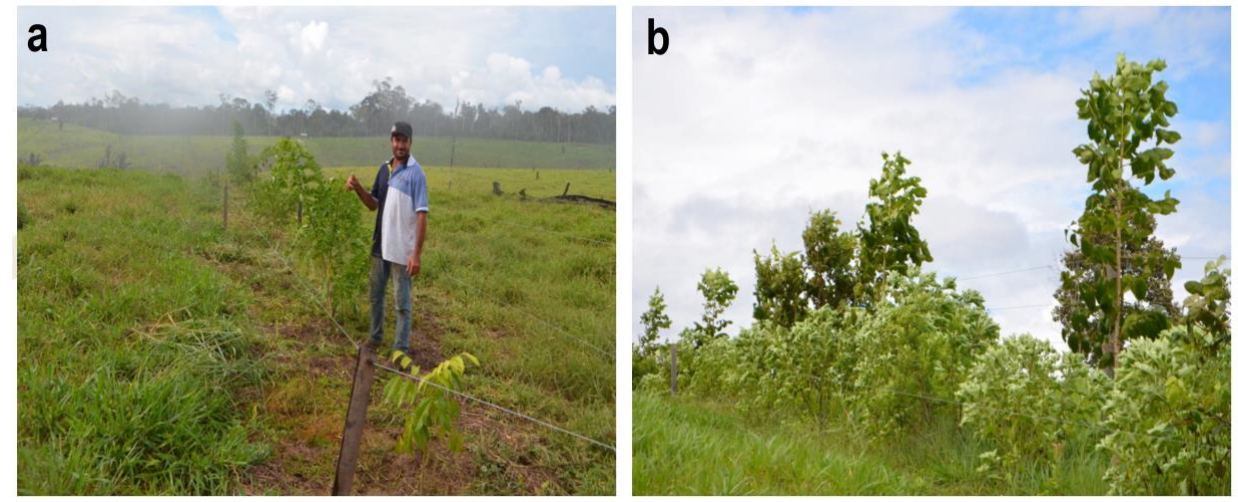

Figure 8. (a) Producer standing with a tree line of 4-month old leguminous trees in an Idesam silvopastoral system; (b) silvopastoral system once the bushes and trees are 2 years old.

Silvopastoral systems do, however, require careful management and substantial initial investment. Trees need protection from heavy grazing for the first 12-24 months post-planting; thereafter they require occasional pruning if they get too broad in order to avoid excessive shade hindering grass growth [59]. Farmers must also closely monitor herd performance, including daily recording of stocking rates. These changes require on average a $20 \%$ increase in on-farm labor. Farmers are supported throughout the process by monthly visits from Idesam's agricultural extension staff. Costs of implementing silvopastoral systems are high, $\mathrm{R} \$ 2400-3020 / \mathrm{ha}$, though this is offset by low maintenance costs around $\mathrm{R} \$ 220 / \mathrm{ha} / \mathrm{yr}$, in part because leguminous pastures do not require any nitrogen fertilizer application.

While it is hoped that productivity increases will reduce greenhouse gas emissions on participating farms, a recent analysis found that participating farms had higher greenhouse gas emissions than neighboring farms (47 vs. $40 \mathrm{~kg} \mathrm{CO} 2 \mathrm{e} / \mathrm{kg}$ beef) [8]. These results should, however, be treated with caution as the analysis used the Cool Farm Tool, an out-of-the-box greenhouse gas calculator which is not tailored for measuring emissions from integrated systems, and the input data were collected less than one year after the program's implementation. The environmental and economic impacts of integrated systems, such as silvopastoral systems, are difficult to model because the different parts of the management system interact [60], in this case, leguminous trees fertilize the pasture, supporting grass growth. The Cool Farm Tool, though comprehensive in many respects, does not consider these interactions, simplifying the farm's environmental footprint and potentially over-estimating emissions. 
Similarly, while the Cool Farm Tool can calculate carbon sequestered in trees on-farm, this source of sequestration was not included in Bogaerts et al. [8]. Additionally, the farm-level data used were collected shortly after the implementation of rotational grazing, therefore, emissions associated with pasture improvement were counted before productivity gains had been realized. As it is expected to take five years for the systems to achieve full productivity (Table 2), using data from only the first year overestimates emissions from participating farms.

Finally, to participate in the initiative, farms must also be compliant with environmental legislation. They must be registered on the CAR, develop a PRAD (the "Projeto de Recomposição de Áreas Degradadas e/ou Alteradas", a plan for restoration if the property does not meet minimum legal requirements for forest cover), and agree to not clear any new areas of forest.

\subsection{Dairy Case Study \#1—Silvopastoral System with Rotational Grazing for Dairy}

Idesam also work with 11 smallholder pilot farms (ranging from 83-340 ha in size; Table 1) in the state of Amazonas, to increase dairy productivity through the rotational management of pasture lined with timber and leguminous trees, and shrubs. As for Idesam's beef intensification in the region, the dairy initiative has seen productivity improvements, a 1.26-fold increase in milk production per cow and 4.9-fold increase in milk production per hectare (Table 3).

Plots of intensively managed pasture are divided by doubled electric fences protecting a line of trees and shrubs. Compared with Idesam's beef system, the dairy farms use a greater number of plots ( 40) and trees (50 to 110/ha). Around 6 hectares is targeted for intensive management on each farm, with 0.1 to 0.9 hectares per plot. Forty-four percent of the tree species were planted to provide shade for cattle and timber as a source of long-term income for farmers; $56 \%$ were leguminous [61]. As often required in the region, the soil was supplemented with lime, before planting Brachiaria brizantha, Panicum maximum cv. BRS zuri or cv. Massai grasses, with phosphorus added as necessary. These grasses show high productivity in the shady conditions typical of silvopastoral systems $[57,62]$. Laboratory experiments have shown, for example, that shade can even increase the protein content of Panicum maximum grasses [63].

The system is managed in rotation, where cattle are moved through plots every $12 \mathrm{~h}$ to two days, depending on grass height. In the drier months, the deep-rooted leguminous trees continue to provide a source of fodder, and some farmers supplement feed with maize silage or "cut-and-carry" feeding of Tithonia diversifolia, Inga edulis, and Cratylia argentea. Lactating cattle on some farms also receive $1.5 \mathrm{~kg}$ of maize-based concentrate feed at milking each day. Water availability is crucial for high-productivity dairy production, and so drinking water is pumped into elevated water boxes, which distribute it by gravity through a system of buried hoses to each pasture plot (Figure 9).
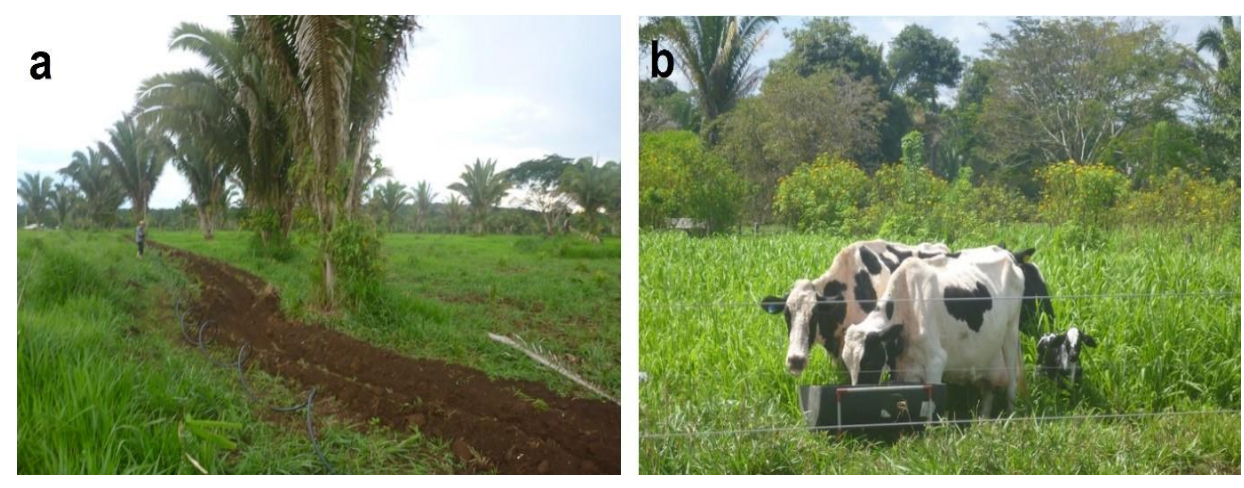

Figure 9. (a) Installation of underground piping to deliver water to each plot in the Silvopastoral System with Rotational Grazing for Dairy initiative; (b) Dairy cattle drinking from one of the water troughs, with electric fencing in the foreground. 
Systems with leguminous trees require approximately 15\% more labor than conventional pasture-based systems. The trees require protection from grazing and insects for the first few months, as well as intermittent pruning during the first three years. The requirement for tree care reduces as the trees mature, and the rotational management of cattle in these systems requires no additional specific management, as cattle are moved twice a day for milking in any case.

The implementation of leguminous systems can be costly, ranging from $\mathrm{R} \$ 4900-6900 /$ ha to cover the costs of pasture reformation, tree planting, electric fencing (for managing rotational grazing), and construction of water sources in each plot (Table S3, Supplementary Material). Though these initial costs are paid off within 2-7 years (Table 3), as improved management boosts profitability from $\mathrm{R} \$ 1281.15 / \mathrm{ha} / \mathrm{yr}$ to around $\mathrm{R} \$ 4425 / \mathrm{ha} / \mathrm{yr}$, Idesam has provided financial support to the first farmers of the program. Farmers paid $20 \%$ of the cost of implementation, with Idesam covering the remaining $80 \%$. To access this financial support and participate in the initiative, farmers must commit to legal compliance with the Forest Code. Farms must be registered in the CAR, commit to not deforest further, and restore non-forested areas and degraded riparian strips, in line with the PRAD.

\subsection{Dairy Case Study \#2-Florestas de Valor}

The dairy intensification project Florestas de Valor ("Forests of Value" in English) was launched by the Institute of Forestry and Agricultural Management and Certification (Portuguese acronym, IMAFLORA) in 2015, and operates on six farms in São Félix do Xingu in the state of Pará. By concentrating production on a small, intensively managed portion of pasture in each farm, they have increased stocking rates almost three-times above the regional average, with $85 \%$ higher productivity per cow (3240 L milk/cow/yr vs. $1750 \mathrm{~L} / \mathrm{cow} / \mathrm{yr}$; Table 3).

Florestas de Valor operates on small properties, ranging from 25-200 hectares in size (Table 1). These farms rely almost entirely on family labor, and so it is important that the intensification does not increase the overall requirement for labor. This is achieved by focusing production on a small area in each farm, where 3.5-11 hectares are selected for intensification and divided into 10-15 fenced plots (Figure 10). The soil in each plot is analyzed before soil correction, and either direct resowing with Brachiaria brizantha MG5, Panicum maximum cv. Mombaça, Brachiaria decumbens or Panicum maximum cv. Massai, or pasture restoration through crop-livestock integration. On four properties, maize was planted on degraded pasture; once the maize was harvested, pasture grasses were then sown. The fences between pasture plots are planted with leguminous trees, including Canavalia ensiformis, Inga edulis and Cajanus cajan. Trees were planted three meters apart, with an average of 66 trees per hectare. Cattle remain approximately three days in each plot, thereby completing a cycle of each plot every 30-45 days. In the dry season, when grass growth is slower and over-grazing is more likely, less time is spent in the fenced plots, and cattle are instead put onto pasture that has been intentionally rested.

Overall, it costs around $\mathrm{R} \$ 2500 /$ ha to implement the rotational grazing and leguminous tree systems. These costs stem from costs of soil improvement, grass seeds, maize planting, fencing, solar panels, and in-pasture water sources (Table S3, Supplementary Material). Of the 50 hectares intensified, IMAFLORA funded 36 hectares, with farmers covering the costs of the remaining 14 hectares. In either case, because of improvements in productivity, the total initial cost is expected to be paid off within $3-5$ years. 


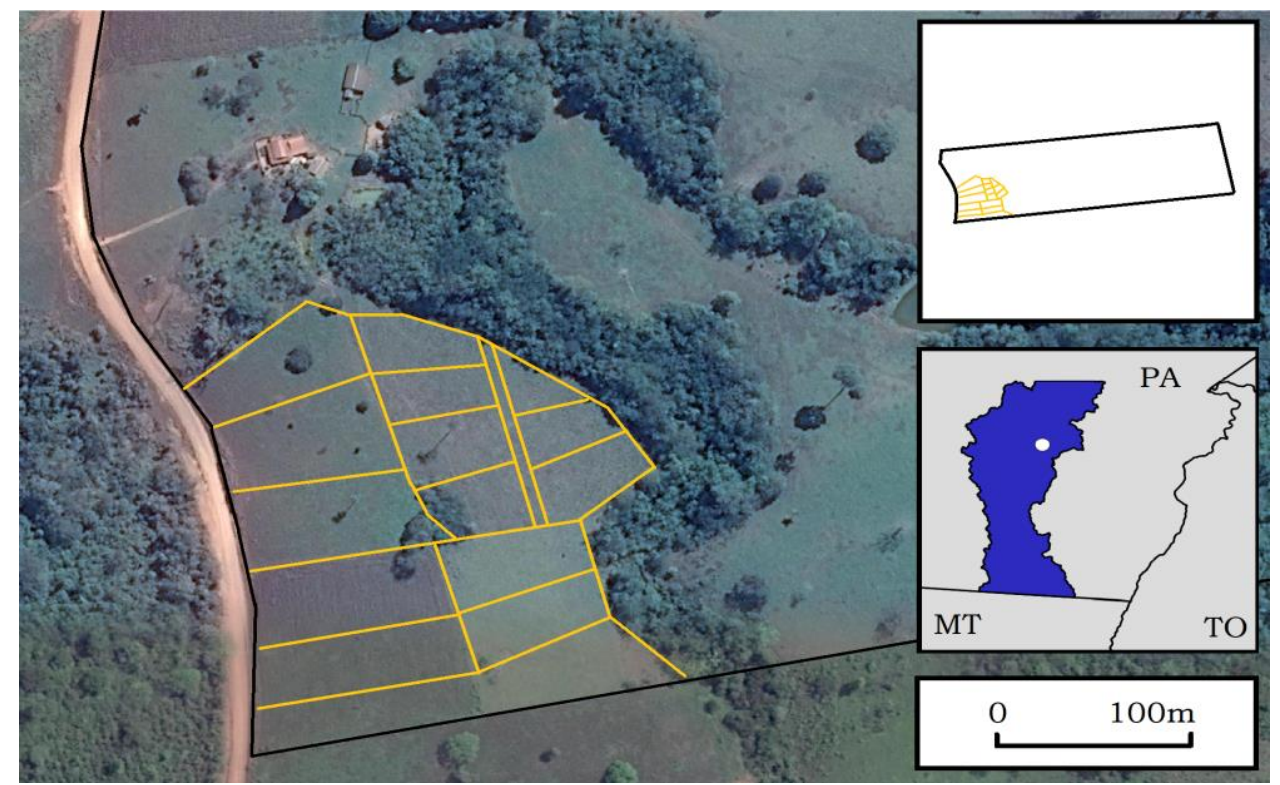

Figure 10. Around $10 \%$ of each property in the Florestas de Valor initiative is divided into small plots using fences lined with leguminous trees (yellow lines in the main image). Top right: intensified pasture area shown within the total farm boundary (black line). Lower right: The farm location is shown as a point within Sao Felix do Xingu (municipality colored in blue). State abbreviations: PA = Pará, $\mathrm{MT}=$ Mato Grosso, $\mathrm{TO}=$ Tocantins.

\section{Discussion}

The results from these initiatives suggest that there are a variety of available technologies that can increase cattle ranching productivity and profitability in the Amazon. Though diverse in the details, these initiatives share many similarities, including their focus on farmer training, farm record-keeping, and improved pasture management, in particular, the adoption of rotational grazing and pasture fertilization using chemical inputs or leguminous plants. These management changes require some initial investment (R $\$ 1300-6900 /$ hectare), which is paid off within 2.5-8.5 years.

With the exception of the introduction of grass-legume pastures in Acre, the initiatives presented are young and further productivity gains are expected, with productivity expected to peak 1.5-7 years after implementation (Tables 2 and 3). Our study is, however, not a large-scale randomized controlled trial, and so these promising results come with a number of caveats. First, we do not claim that our review is exhaustive, though we present results from six of the thirteen initiatives that we are aware of which operate in the region (Table S4, Supplementary Material), and we believe our results are broadly representative of high-yielding cattle ranching in the Amazon. Second, these initiatives recruited farmers opportunistically, predominantly through farmer networks and open farm days (Figure 11). The farmers participating are therefore "early-adopters", who may differ from other farmers in systematic ways, for example by being less risk averse. We do not believe that the productivity gains that we observe result from these farmer differences or fundamental differences between these farms and their neighbors. For three of our six initiatives, we present productivity estimates from before and after the interventions showing clear productivity increases (for the other three, the Novo Campo Program, Florestas de Valor and mixed legume pastures in Acre, pre-intervention data were not available and our baseline data are estimates of the regional average productivity; Tables 2 and 3). Our data are also self-reported, though our productivity improvements are in line with previous literature on the productivity gains from improvements in farm management in Brazil [5,64-67], and our estimates of the costs of intensification are an important resource for accurately estimating the cost-effectiveness of cattle intensification in the Amazon. Previous work on 
the cost of cattle intensification has typically focused only on direct costs of pasture improvement, thereby underestimating the true cost of intensification for farmers. When modelling the pasture improvement included in Brazil's contribution to the UNFCC, De Oliveira Silva et al. [5], for example, estimate costs between $R \$ 365-1243 /$ ha and maintenance costs from $R \$ 6.9-266.8 /$ ha, estimates which are substantially lower than our figures. Their figures, however, do not include indirect costs such as costs from the transportation of inputs, increased labor, or costs from fencing and the implementation of rotational grazing.

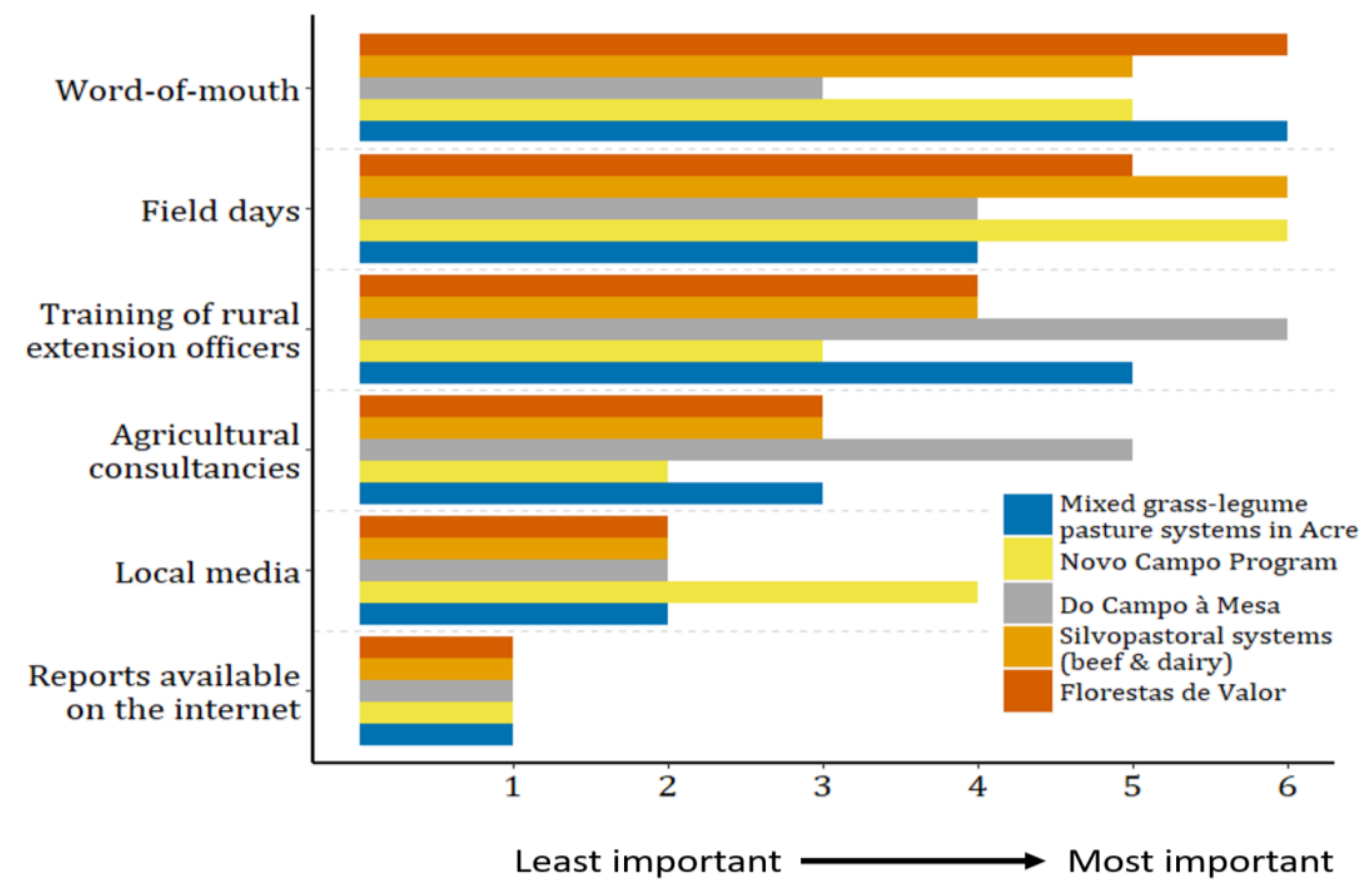

Figure 11. Relative importance $(1=$ least important, $6=$ most important $)$ of six different channels for recruiting farmers into the six initiatives described in this article. All initiatives recruited farmers opportunistically, as knowledge about the initiatives was spread for the most part through word-of-mouth, field days where neighboring farmers were invited to tour participating farms, and the training of rural extension officers in GAP. Idesam's beef and dairy initiatives took similar approaches to recruitment, and so the results are grouped for these two initiatives.

\subsection{Risks of Cattle Intensification}

Whatever the financial costs, increasing cattle ranching yields in the Amazon is not without risks [68]. Improving productivity can reduce greenhouse gas emissions from beef production, as seen both at the farm-scale in the Novo Campo Program (Figure 6) and other intensification initiatives in the region [8], and at the national-scale from coupled economic-environmental modelling [6]. Cohn et al. [6] find that the adoption of GAP in Brazil could halve greenhouse gas emissions from deforestation and agriculture, though in practice the land sparing effect of cattle productivity increases are likely to vary spatially. While in consolidated regions, economic theory suggests that intensification can help reduce deforestation through market and labor effects [69,70], in forested regions intensification risks rebound effects-the so-called "Jevon's paradox" where increases in the profitability of cattle ranching incentivize, rather than reduce, local deforestation. Reconciling targets for increased cattle production and zero illegal deforestation or even deforestation-free production will therefore require explicitly linking improvements in cattle ranching with habitat protection and efforts to reduce leakage in cattle supply chains [71,72]. It is also with this rebound effect in mind that the initiatives described in this article explicitly require participating farmers to comply with the Brazilian 
Forest Code, have no recent illegal deforestation, and develop land use plans for reforestation where required. Further discussion of potential risks is included in the online Supplementary Material.

While the technologies discussed in this article can increase farm profitability, this is also not always the case; results from two of our initiatives show that pasture intensification may, in some cases, be more profitable on large, rather than small farms. In the do Campo à Mesa initiative, pasture intensification was not profitable within twelve years for the two smallest farms, suggesting that there is a tipping point in economic returns between 126 and 425 ha of pasture [37]. Similar economies of scale were found in a modelling study using data from the Novo Campo Program (which found that the introduction of GAP and rotational grazing intensification was only profitable on farms with $>385$ ha of pasture; IIS, 2015), and in other studies of cattle ranching economics [4,73]. On the other hand, these economies of scale appear to be technology and system dependent. Positive economic returns were seen for smallholder dairy producers, and silvopastoral beef systems in Apuí (Tables 2 and 3), which can turn a profit with as little as 20 hectares of pasture. Similarly, grass-legume pastures have been adopted by small- and large-farms alike in Acre [41,74]. Given that $78 \%$ of cattle-rearing farms (hosting 33\% of cattle) in the Amazon biome have less than 200 hectares of pasture (Figure S2, Supplementary Material), it is important that efforts to improve profitability and farmer livelihoods in the cattle sector include both large- and small- landholders.

\subsection{Barriers to Scaling up Sustainable Cattle Ranching}

Cattle production in Brazil is set to grow; the Brazilian government recently set ambitious targets for increasing beef and dairy production by $40 \%$ [75]. The sustainable growth of the industry is not, however, guaranteed. To ensure that the cattle industry develops sustainably, improving farmer livelihoods while protecting the environment, will require a mix of the right financial incentives, efforts to support training of rural workers and agricultural extension services, and improved monitoring of cattle supply chains.

Most cattle ranchers adopt good agricultural practices because of the expected improvements in productivity and profitability [76]. However, implementation costs and difficulty in accessing credit are barriers for many producers. Among producers surveyed in Mato Grosso regarding adoption of good agricultural practices, $18 \%$ cited financial constraints as a barrier to adoption [76], and high implementation costs are also an important barrier for four of the six cattle initiatives described in this article (Figure 12).

(a) Barriers

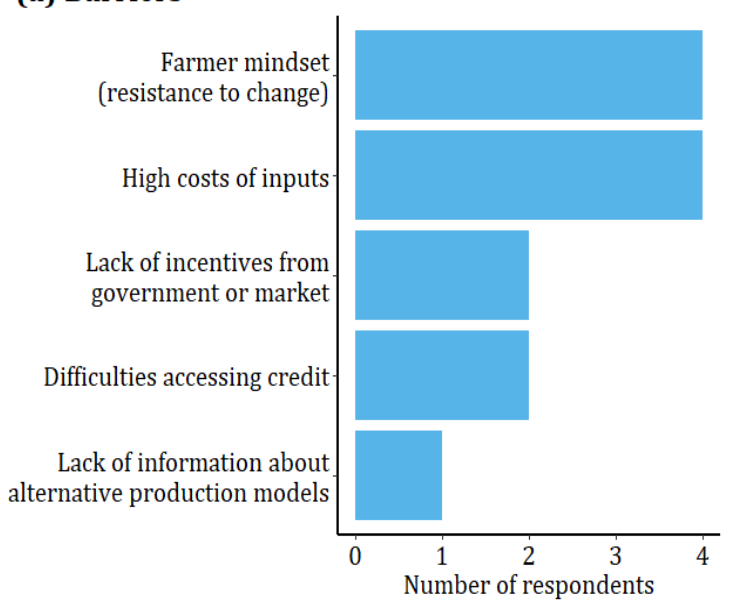

\section{(b) Solutions}

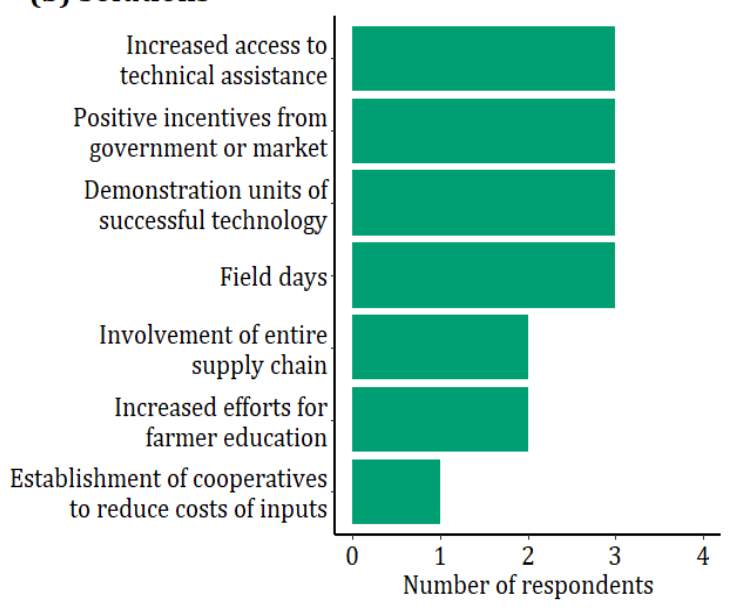

Figure 12. (a) The most important barriers to the implementation of sustainable cattle initiatives, and (b) the solutions to these barriers, as identified in the survey of the organizations running the six sustainable cattle ranching initiatives described in this article. 
Sustainable growth in the cattle industry must also combine productivity improvements with the protection of native vegetation. In the Amazon biome, farmers are required to keep $80 \%$ of their land under forest (the threshold is set at 50\% for small properties and properties in Ecological and Economic Zoning areas), and must reforest any land deforested above this threshold, or purchase certificates through the nascent forest trading scheme to compensate [77]. As the forest certificate market is not yet operating at scale, farmers currently rely on on-site reforestation for legal compliance, and the costs can be substantial. The do Campo à Mesa and Novo Campo Program initiatives report reforestation costs of $R \$ 868-6068 /$ ha and $R \$ 2360-9654 /$ ha, respectively. These figures are roughly equivalent to the costs of pasture intensification and implementation of GAP. Unfortunately, even where farmers can access credit, no credit lines currently support costs of compliance with the Forest Code [37].

The financial barriers to improved cattle production and compliance with the Forest Code can, however, be overcome by developing the right private and public incentives for producers (Figure 12). Currently, farmers receive the same price for their product, regardless of their environmental management. This could be fixed by the development of sustainable beef price premiums and certification schemes, such as the "Standard for Sustainable Cattle Production Systems" developed by the Sustainable Agricultural Network, which delivers a financial reward to producers implementing good practices [78]. Similarly, agricultural credit can be leveraged for sustainability, by making access to agricultural credit contingent on the adoption of sustainable ranching practices, and by supporting the costs of meeting the requirements of the Forest Code.

As an example of sustainable credit, in 2010 Brazil created the landmark ABC Program, one of the world's first credit lines for low carbon agriculture [79], which supports the costs of restoring degraded pasture and the implementation of integrated crop-livestock-forestry systems. The impact of the ABC Program has, however, been hampered by bureaucratic issues, unfavorable interest rates, and a lack of public awareness. Producers perceive the ABC program as being complex, slow, and overly bureaucratic [76] - posing a particular problem for small producers [80]. The ABC Program is often out-competed by other credit lines; its interest rates (7.5-8\% per year) are double that of loans available through the National Rural Credit System, Brazil's main source of agricultural credit [79]. Public awareness is also a problem. Surveys in the Alta Floresta region of Mato Grosso show that most producers have not heard of the ABC Program and are not familiar with the concept of sustainable credit lines [80]. Only 10\% of the ABC Program's budget is spent in the northern states, which make up the majority of the Amazon biome [81]. Overall, sustainable credit lines make up only $1.9 \%$ of all agricultural credit in Brazil [79], and there are currently no sustainable credit lines which are specifically aimed at smallholders, though these could be created within the existing National Program for Strengthening Family Agriculture (Portuguese acronym, PRONAF) [79].

The widespread adoption of sustainable cattle ranching will, of course, require more than just the correct mix of financial incentives. Barriers are also posed by a shortage of trained labor, farmer risk aversion, and the complexity of cattle supply chains. Improved farm performance cannot be achieved without the adequate training of farm staff. The lack of qualified labor is, however, acute in both beef and dairy production [76,82]. Sixty-five percent of ranchers surveyed in Alta Floresta, Mato Grosso, cited a shortage of qualified labor as the main barrier to the adoption of good agricultural practices [76]. Access to agricultural extension services is also limited [11]. Four-fifths of dairy farmers in Mato Grosso, for example, have never received technical assistance [28].

Farmer psychology also plays an important role (Figure 12). High-yielding cattle ranching costs more in the short term, though it generates positive returns in the longer-term (Tables 2 and 3 ). Many cattle ranchers are, however, risk averse [4] or not motivated by profit-maximization [83], and the transition from low-input, low-risk extensive systems to intensive pasture management requires to some degree a shift in mindset. Improved farm management begins with improved record-keeping, which is a foreign concept to most producers [4]. Rotational grazing systems also require that cattle are moved more frequently. Nelore cattle breeds have a reputation as being difficult to handle, though this is in large part because in extensive systems they are not used to contact with farm staff. While regular 
contact with farm laborers does improve their temperament [84], farmers can at first take some convincing about the feasibility of new management practices. The required shift in mindset is perhaps even greater for the adoption of silvopastoral systems and mixed grass-legume pastures. Farmers used to thinking of cattle as animals which graze grass may be initially reluctant to incorporate trees or herbaceous legumes (usually considered as undesirable species) into pasture as a source of forage and fertilizer.

These psychological barriers can perhaps be overcome by increasing familiarity with high-yielding systems, which remains low [80]. Awareness can be raised by establishing demonstration units on real farms, as in the six initiatives described in this article, and open-farm field days so that local farmers can witness and learn about new management options (Figure 11). As Brazilian farmers' receive most of their farming advice from other farmers [85], word-of-mouth dissemination of new technologies is critical, and can be effective, as seen in the experiences of legume pastures in Acre. The existence of local champions, long-term commitment of key players, and strategic partnerships among local stakeholders are also key to successful wide adoption of intensive cattle production systems [41].

Finally, there are structural barriers to sustainable cattle ranching. Cattle supply chains are complex, which means that deforestation is difficult to eradicate. While market initiatives (such as the "Terms of Adjustment of Conduct" and "G4" agreements) require meatpacking companies to block sales from properties with illegal deforestation (the G4 prohibits new deforestation altogether), this applies only to properties which supply cattle directly to slaughterhouses. As cattle may be born on one ranch, reared on a second, and fattened on a third, leakage is widespread. Though these agreements have reduced deforestation among the direct suppliers of slaughterhouses, it has not led to overall reductions in deforestation [71]. To permit growth of the Brazilian beef industry while reducing deforestation will therefore require efforts to reduce leakage. This could be achieved either by monitoring the movements of individual cattle, for example, using unique ear tags, or by monitoring farm-to-farm movement of batches of cattle. This information is already collected as part of the Guide to Animal Transport (GTA) used to track animal sanitation and health, but it is not used for monitoring environmental compliance.

While the barriers to scaling-up high-yielding cattle ranching in the Amazon are numerous, there is cause for optimism. First, cattle productivity is already increasing in most regions of Brazil $[13,86]$. Second, the example of leguminous pasture adoption in Acre shows that local demonstration farms can lead to technology diffusion at a regional scale in the Amazon. Third, though focused in southern Brazil, lessons can be learned from the dairy extension initiative, the Projeto Balde Cheio ("Full Bucket" project in English). The program began in 1999 in two municipalities in the states of São Paulo and Minas Gerais, where demonstration units were established on twelve farms. Operating on a budget of only R $\$ 5000-45,000$ (US\$5000-23,000) per year, agricultural extension officers from Embrapa worked with farmers to introduce a package of new practices, including improved farm book-keeping, soil conservation, pasture fertilization, and rotational management. On average, family farmers who joined the program increased milk production three-fold [82], with higher productivity arising from a combination of more lactating cows/area (31\%), higher productivity/cow (24\%), and better labor performance (37\%), while using less land area $(-7 \%)$. The initiative has since expanded, as the number of farmers assisted rose from 400 in 2010 to more than 3000 in 2012, and is now present in 483 municipalities nationwide, including farms in Rondônia, Pará and Amazonas, within the Amazon biome (Table S4, Supplementary Material).

\section{Conclusions}

As cattle ranching makes up the majority of agricultural land and productivity is still well below its sustainable potential, improvements in cattle productivity are key to the sustainable intensification of Brazilian agriculture. We present results from six cattle ranching initiatives which have achieved higher productivity and profitability in the Brazilian Amazon, while also supporting compliance with the Forest Code. These initiatives are, for the most part, still young and so we conclude by setting out 
three key conditions which are required to mainstream sustainable cattle ranching in the Amazon. If these conditions are met, we believe that the Brazilian beef industry can profitably produce more on less land and thereby facilitate growth in the agricultural sector while protecting Brazil's remaining native vegetation.

(1) Large-scale knowledge transfer-long-term funding and support is required for farmer-centered agricultural extension services, which increase awareness of high-yielding technologies and support small- and large-holders alike to adopt appropriate farming practices.

(2) Financial support for sustainable cattle ranching-farmers must be incentivized to adopt sustainable ranching practices, both through competitive, sustainable credit lines and through market signals. Rural credit lines should include sustainability criteria, and should help farmers not only increase agricultural production, but also meet the costs of Forest Code compliance. Market signals also matter, and just as some slaughterhouses offer price-premiums for high meat quality, price-premiums for GAP would encourage farmer uptake.

(3) Increase transparency in cattle supply chains-efforts by some slaughterhouses to monitor direct suppliers are a step in the right direction, but do not go far enough. All slaughterhouses should monitor both indirect and direct cattle suppliers, and monitoring efforts should be independently audited and publicly reported, so that deforestation may ultimately be eliminated from cattle supply chains.

Supplementary Materials: The following are available online at http:/ /www.mdpi.com/2071-1050/10/4/1301/s1, supplementary text about the risks of cattle intensification; Tables S1-S4, and Figures S1 and S2.

Acknowledgments: We thank Fabio Ramos, Daniel Silva, André Novo, Artur Camago, Abdias Machado, Kemel Kalif, Márcio Rangel, Ezequiel Rodrigues do Valle, Marcelo Stabile, Mariano Cenamo, João Pedro Pio, Toby Gardner, Ben Phalan, Javier Godar, Livia Matyucheva, Priscila da Cunha Lessa, and Jose Guerrero for their input at various stages of the project. Erasmus K.H.J. zu Ermgassen was funded by BBSRC grant BB/J014540/1 and the Tim Whitmore Trust Fund. Funding for open access publishing come from BBSRC grant BB/J014540/1.

Author Contributions: Erasmus K.H.J. zu Ermgassen co-designed the study, wrote the survey, collected the data, analysed the data, and led on the writing of the manuscript. Bernardo B.N. Strassburg and Agnieszka Latawiec co-designed the study; Melquesedek Pereira de Alcântara, Francisco Beduschi Neto, Murilo M. F. Bettarello, Genivaldo de Brito, Gabriel C. Carrero, Eduardo de A.S. Florence, Edenise Garcia, Eduardo Trevisan Gonçalves, Casio Trajano da Luz, Giovanni M. Mallman, and Judson F. Valentim provided data, and all co-authors contributed substantially to the writing of the manuscript.

Conflicts of Interest: This manuscript reports the results of six initiatives which have increased the productivity of cattle ranching in the Brazilian Amazon. Many of the authors (Melquesedek Pereira de Alcântara, Francisco Beduschi Neto, Murilo M.F. Bettarello., Genivaldo de Brito, Gabriel C. Carrero, Eduardo de A.S. Florence, Edenise Garcia, Eduardo Trevisan Gonçalves, Casio Trajano da Luz, Giovanni M. Mallman, Bernardo B.N. Strassburg, Judson F. Valentim, and Agnieszka Latawiec) were directly involved in the development of these initiatives. The founding sponsors had no role in the design of the study; in the collection, analyses, or interpretation of data; in the writing of the manuscript, and in the decision to publish the results.

\section{References}

1. FIESP Outlook FIESP 2026: Projections for Brazilian Agribusiness; Federação das Indústrias do Estado de São Paulo: São Paulo, Brazil, 2016.

2. Brazil Intended Nationally Determined Contribution towards Achieving the Objective of the United Nations Framework Convention on Climate Change. Available online: http://www4.unfccc.int/submissions / INDC/Published\%20Documents/Brazil/1/BRAZIL\%20iNDC\%20english\%20FINAL.pdf (accessed on 16 April 2018).

3. Strassburg, B.B.N.; Latawiec, A.E.; Barioni, L.G.; Nobre, C.A.; da Silva, V.P.; Valentim, J.F.; Vianna, M.; Assad, E.D. When enough should be enough: Improving the use of current agricultural lands could meet production demands and spare natural habitats in Brazil. Glob. Environ. Chang. 2014, 28, 84-97. [CrossRef]

4. Barbosa, F.A.; Soares Filho, B.S.; Merry, F.D.; de Oliveira Azevedo, H.; Costa, W.L.S.; Coe, M.T.; da Silveira Batista, E.; Maciel, T.C.; Sheepers, L.C.; de Oliveira, A.R.; et al. Cenários para a Pecuária de corte Amazônica; Universidade Federal de Minas Gerais: Belo Horizonte, Brazil, 2015; p. 154. 
5. De Oliveira Silva, R.; Barioni, L.G.; Queiroz Pellegrino, G.; Moran, D. The role of agricultural intensification in Brazil's Nationally Determined Contribution on emissions mitigation. Agric. Syst. 2018, 161, 102-112. [CrossRef]

6. Cohn, A.S.; Mosnier, A.; Havlik, P.; Valin, H.; Herrero, M.; Schmid, E.; O’Hare, M.; Obersteiner, M. Cattle ranching intensification in Brazil can reduce global greenhouse gas emissions by sparing land from deforestation. Proc. Natl. Acad. Sci. USA 2014. [CrossRef] [PubMed]

7. De Oliveira Silva, R.; Barioni, L.G.; Hall, J.A.J.; Moretti, A.C.; Fonseca Veloso, R.; Alexander, P.; Crespolini, M.; Moran, D. Sustainable intensification of Brazilian livestock production through optimized pasture restoration. Agric. Syst. 2017, 153, 201-211. [CrossRef]

8. Bogaerts, M.; Cirhigiri, L.; Robinson, I.; Rodkin, M.; Hajjar, R.; Costa Junior, C.; Newton, P. Climate change mitigation through intensified pasture management: Estimating greenhouse gas emissions on cattle farms in the Brazilian Amazon. J. Clean. Prod. 2017, 162, 1539-1550. [CrossRef]

9. Piccoli, M.L.; Braccini Neto, J.; Brito, F.V.; Campos, L.T.; Bértoli, C.D.; Campos, G.S.; Cobuci, J.A.; McManus, C.M.; Barcellos, J.O.J.; Gama, L.T. Origins and genetic diversity of British cattle breeds in Brazil assessed by pedigree analyses. J. Anim. Sci. 2014, 92, 1920-1930. [CrossRef] [PubMed]

10. Townsend, C.R.; de Lucena Costa, N.; de Araújo Pereira, R.G. Aspectos Econômicos da Recuperação de Pastagens no Bioma Amazônia; EMBRAPA: Porto Velho, Brazil, 2009; p. 28.

11. Valentim, J.F. Desafios e estratégias para recuperação de pastagens degradadas e intensificação da pecuária a pasto na Amazônia Legal. In Simpósio de Pecuária Integrada; Pereira, D.H., Carneiro e Pedreira, B., Eds.; Recuperação de Pastagens: Anais; Fundação Uniselva: Cuiabá, Brazil, 2016; pp. 11-56.

12. Dias-Filho, M.B.; Andrade, C.M.S. De Pastagens no Trópico Úmido; Embrapa Amazônia Oriental: Belém, Brazil, 2006; p. 33.

13. Dias, L.C.P.; Pimenta, F.M.; Santos, A.B.; Costa, M.H.; Ladle, R.J. Patterns of land use, extensification, and intensification of Brazilian agriculture. Glob. Chang. Biol. 2016, 22, 2887-2903. [CrossRef] [PubMed]

14. Bowman, M.S.; Soares-Filho, B.S.; Merry, F.D.; Nepstad, D.C.; Rodrigues, H.; Almeida, O.T. Persistence of cattle ranching in the Brazilian Amazon: A spatial analysis of the rationale for beef production. Land Use Policy 2012, 29, 558-568. [CrossRef]

15. Ministério da Agricultura, Pecuária e Abastecimento; Ministério da Ciência, Tecnologia, Inovações e Comunicações; Ministério do Meio Ambiente. Projeto Terraclass 2012; Embrapa \& INPE: Brasília, Brazil, 2014.

16. Börner, J.; Kis-Katos, K.; Hargrave, J.; König, K. Post-Crackdown Effectiveness of Field-Based Forest Law Enforcement in the Brazilian Amazon. PLoS ONE 2015, 10, e0121544. [CrossRef] [PubMed]

17. Soares-Filho, B.; Moutinho, P.; Nepstad, D.; Anderson, A.; Rodrigues, H.; Garcia, R.; Dietzsch, L.; Merry, F.; Bowman, M.; Hissa, L.; et al. Role of Brazilian Amazon protected areas in climate change mitigation. Proc. Natl. Acad. Sci. USA 2010, 107, 10821-10826. [CrossRef] [PubMed]

18. Gibbs, H.K.; Rausch, L.; Munger, J.; Schelly, I.; Morton, D.C.; Noojipady, P.; Soares-Filho, B.; Barreto, P.; Micol, L.; Walker, N.F. Brazil's Soy Moratorium. Science 2015, 347, 377-378. [CrossRef] [PubMed]

19. Assunção, J.; Gandour, C.; Rocha, R. Deforestation slowdown in the Brazilian Amazon: Prices or policies? Environ. Dev. Econ. 2015, 20, 697-722. [CrossRef]

20. Tollefson, J. Deforestation spikes in Brazilian Amazon. Nature 2016, 540. [CrossRef]

21. Carrero, G.; Fearnside, P. Forest Clearing Dynamics and the Expansion of Landholdings in Apuí, a Deforestation Hotspot on Brazil's Transamazon Highway. Ecol. Soc. 2011, 16. [CrossRef]

22. Datu Research. Deforestation and the Brazilian beef Value Chain; Datu Research: Durham, NC, USA, 2014.

23. Merry, F.; Soares-Filho, B. Will intensification of beef production deliver conservation outcomes in the Brazilian Amazon? Elem. Sci. Anth. 2017, 5, 24. [CrossRef]

24. Richards, P.D.; Walker, R.T.; Arima, E.Y. Spatially complex land change: The Indirect effect of Brazil's agricultural sector on land use in Amazonia. Glob. Environ. Chang. 2014, 29, 1-9. [CrossRef] [PubMed]

25. IBGE Pesquisa Pecuária Municipal (PPM). Available online: https://sidra.ibge.gov.br/pesquisa/ppm/ quadros/brasil/2015 (accessed on 24 April 2017).

26. PRODES Desflorestamento nos Municipios. Available online: http://www.dpi.inpe.br/prodesdigital/ prodesmunicipal.php (accessed on 26 April 2017).

27. Pacheco, P. Actor and Frontier Types in the Brazilian Amazon: Assessing Interactions and Outcomes Associated with Frontier Expansion. Geoforum 2012, 43, 864-874. [CrossRef] 
28. Gomes, S.T.; Instituto Mato-Grossense de Economia Agropecuária. Diagnóstico da Cadeia do Leite no Estado de Mato Grosso; Famato, Senar-MT, \& Sescoop-MT: Cuiabá, Brazil, 2012; p. 103.

29. Zoccal, R.; Alves, E.R.; Gasques, J.G. Diagnóstico da Pecuária de Leite nacional: Estudo Preliminar. Contribuição para o Plano Pecuário 2012; Embrapa Gado de Leite: Juiz de Fora, Brazil, 2011.

30. Santana, M.L.; Pereira, R.J.; Bignardi, A.B.; El Faro, L.; Tonhati, H.; Albuquerque, L.G. History, structure, and genetic diversity of Brazilian Gir cattle. Livest. Sci. 2014, 163, 26-33. [CrossRef]

31. Eurostat Database Agriculture Statistics. Available online: http:/ / ec.europa.eu/eurostat (accessed on 9 January 2014).

32. Livestock Improvement Corporation (LIC); DairyNZ. New Zealand Dairy Statistics 2013-14; Livestock Improvement Corporation Limited and DairyNZ Limited: Hamilton, New Zealand, 2014; p. 55.

33. IBGE Censo Agropecuário. Available online: http://www2.sidra.ibge.gov.br/bda/acervo/acervo2.asp?e= $\mathrm{v} \& \mathrm{p}=\mathrm{CA} \& \mathrm{z}=\mathrm{t} \& \mathrm{o}=24$ (accessed on 21 April 2017).

34. Andrade, C.M.S.; de Santos, D.M.; dos Ferreira, A.S.; Valentim, J.F. Técnicas de Plantio Mecanizado de Forrageiras Estoloniferas por Mudas; EMBRAPA: Rio Branco, Brazil, 2016; p. 22.

35. Carrero, G.C. Sistemas Silvipastoris com Pastejo Rotacional: Alternativas Sustentáveis para a Produção Pecuária na Amazônia. In Gestão e Governança Local para a Amazônia Sustentável; notas técnicas; PQGA/IBAM: Belém, Brasil, 2016; pp. 79-91.

36. Carrero, G.C.; Bettarello, M.; Alcântra, A.; Cenamo, M.C. Sistema extensivo versus sistema silvipastoril intensivo para pecuária de leite na Amazônia Brasileira: Produtividade, benefícios socioeconômicos e ecossistêmicos para mitigação e adaptação às mudanças climáticas. In $3^{\circ}$ Congreso Nacional de Sistemas Silvopastoriles-VIII Congreso Internacional de Sistemas Agroforestales; Peri, L., Ed.; Ediciones INTA: Santa Cruz, CA, USA, 2015; pp. 304-308.

37. Garcia, E.; Ramos Filho, F.S.V.; Mallmann, G.M.; Fonseca, F. Costs, Benefits and Challenges of Sustainable Livestock Intensification in a Major Deforestation Frontier in the Brazilian Amazon. Sustainability 2017, 9, 158. [CrossRef]

38. Marcuzzo, S.F.; de Lima, A. A Programa Novo Campo: Estratégia de Pecuária Sustentável na Amazônia; Instituto Centro de Vida: Alta Floresta, MT, Brazil, 2015.

39. Sá, C.P.d; Bayma, M.M.A.; Carvalho, B.P. Avaliação dos Impactos da Tecnologia-Recomendação do Amendoim Forrageiro (Arachis Pintoi) em Pastagens no Acre; EMBRAPA: Rio Branco, Brazil, 2016; p. 18.

40. Valentim, J.F.; Andrade, C.M.S. Tropical kudzu (Pueraria phaseoloides): Successful adoption in sustainable cattle production systems in the western Brazilian Amazon. In Proceedings of the XX International Grassland Congress: Offered Papers; Wageningen Academic Publishers: Wageningen, The Netherlands, 2005.

41. Valentim, J.F.; Andrade, C.M.S. Forage peanut (Arachis pintoi): A high yielding and high quality tropical legume for sustainable cattle production systems in the western Brazilian Amazon. In Proceedings of the XX International Grassland Congress: Offered Papers; Wageningen Academic Pub: Wageningen, The Netherlands, 2005.

42. Andrade, C.M.S. Produção de ruminantes em pastos consorciados. In Proceedings of the Simpósio SOBRE MAnejo Estratégico da Pastagem, Viçosa, MG, Brazil, 11-13 November 2010; pp. 171-214.

43. Panerai, A. Amendoim Forrageiro 2008. Available online: https://pt.slideshare.net/AlexandrePanerai/ amendoim-forrageiro-embrapa (accessed on 8 May 2017).

44. De Sá, C.P.; Andrade, C.M.S.; Valentim, J.F. Análise Econômica para a Pecuária de Corte em Pastagens Melhoradas no Acre; EMBRAPA: Rio Branco, Brazil, 2010; p. 5.

45. Andrade, C.M.S. Importância das Leguminosas Forrageiras para a Sustentabilidade dos Sistemas de Produção de ruminantes. Available online: http:/ / www.sbprc.famev.ufu.br/sites/sbprc.famev.ufu.br/ files/Carlos\%20Maur\%C3\%ADcio\%20Andrade_As\%20leguminosas\%20e\%20a\%20sustentabilidade.pdf (accessed on 20 July 2017).

46. INPE Dados TerraClass 2014. Available online: http://www.inpe.br/cra/projetos_pesquisas/terraclass2014. php (accessed on 22 May 2017).

47. Valentim, J.F.; Andrade, C.M.S. Perspectives of grass-legume pastures for sustainable animal production in the tropics. Reunião Annu. Soc. Bras. Zootec. 2004, 40, 142-154.

48. Henderson, B.B.; Gerber, P.J.; Hilinski, T.E.; Falcucci, A.; Ojima, D.S.; Salvatore, M.; Conant, R.T. Greenhouse gas mitigation potential of the world's grazing lands: Modeling soil carbon and nitrogen fluxes of mitigation practices. Agric. Ecosyst. Environ. 2015, 207, 91-100. [CrossRef] 
49. Costa, F.S.; Sales, M.F.L.; Freitas, A.C.R.; Souza, C.P. Modeling nitrous oxide emissions in grass and grass-legume pastures in the western Brazilian Amazon. In International Symposium on Greenhouse Gases in Agriculture; Embrapa: Brasília, DF, Brazil, 2016; Volume 2.

50. Do Valle, E.R. Lista de verificação: Rebanhos Comerciais; EMBRAPA: Brasília, DF, Brazil, 2013.

51. Cerri, C.C.; Moreira, C.S.; Alves, P.A.; Raucci, G.S.; Castigioni, B.d.A.; Mello, F.F.C.; Cerri, D.G.P.; Cerri, C.E.P. Assessing the carbon footprint of beef cattle in Brazil: A case study with 22 farms in the State of Mato Grosso. J. Clean. Prod. 2016, 112, 2593-2600. [CrossRef]

52. Siqueira, T.T.S.; Duru, M. Economics and environmental performance issues of a typical Amazonian beef farm: A case study. J. Clean. Prod. 2016, 112, 2485-2494. [CrossRef]

53. Piatto, M.; Costa Junior, C. Good Livestock Practices Reduce GHG Emissions and Increase Meat Production in the Amazon; Imaflora: Piracicaba, SP, Brazil, 2016.

54. International Institute for Sustainabilit (IIS). Análise Econômica de Uma Pecuária Mais Sustentável; International Institute for Sustainability: Rio de Janeiro, Brasil, 2015; p. 66.

55. PECSA Pecsa-Pecuária Sustentável da Amazônia. Available online: https://pecsa.com.br/pt/ (accessed on 21 July 2017).

56. Cardona, C.A.C.; Naranjo Ramírez, J.F.; Tarazona Morales, A.M.; Murgueitio Restrepo, E.; Chará Orozco, J.D.; Ku Vera, J.; Solorio Sánchez, F.J.; Flores Estrada, M.X.; Solorio Sánchez, B.; Barahona Rosales, R. Contribution of intensive silvopastoral systems to animal performance and to adaptation and mitigation of climate change. Rev. Colomb. Cienc. Pecu. 2014, 27, 76-94.

57. Broom, D.M.; Galindo, F.A.; Murgueitio, E. Sustainable, efficient livestock production with high biodiversity and good welfare for animals. Proc. R. Soc. B Biol. Sci. 2013, 280. [CrossRef] [PubMed]

58. Burlamaqui Bendahan, A. Système intégré culture-Elevage-Arbre (SILPF) dans l'État du Roraima, Amazonie Brésilienne. 2015. Available online: http:/ /agritrop.cirad.fr/583402/ (accessed on 19 April 2017).

59. Dalzell, S.; Meat \& Livestock Australia. Leucaena: A Guide to Establishment and Management; Meat and Livestock Australia: Sydney, Australia, 2006; ISBN 978-1-74191-013-1.

60. Marton, S.M.R.R.; Zimmermann, A.; Kreuzer, M.; Gaillard, G. Comparing the environmental performance of mixed and specialised dairy farms: The role of the system level analysed. J. Clean. Prod. 2016, 124, 73-83. [CrossRef]

61. Carrero, G.C.; Jacauna, M.A.; Sardinha, A.M.; Bettarello, M. Estabelecimento de árvores nativas de interesse ecológico e econômico para Sistemas Silvipastoris Intensivos em Apuí, Amazônia Brasileira. In III Congresso Internacional de Sistemas Agroforestales_III Congresso Nacional de Sistemas Silvipastoriles, 2015, Iguazú, Argentina. 30 Congresso de Sistemas Silvipastoriles: VIII Congreso Internacional de Sistemas Agroforestales; Ediciones INTA: Santa Cruz, CA, USA, 2015; Volume 1, pp. 21-25.

62. Alvim, M.J.; Paciullo, D.S.C.; de Carvalho, M.M.; Aroeira, L.J.M.; Carvalho, L.d.A.; Novaes, L.P.; Gomes, A.T.; de Miranda, J.E.C.; Ribeiro, A.C.C.L. Sistema de Produção de Leite com Recria de Novilhas em Sistemas Silvipastoris. EMBRAPA Gado de Leite. Available online: https:/ / sistemasdeproducao.cnptia.embrapa.br/FontesHTML/ Leite/LeiteRecriadeNovilhas/index.htm (accessed on 18 April 2017).

63. Silveira, S.R. Valor Nutritivo de Panicum Maximum, Cultivares Tanzania y Massai, de Acuerdo a Niveles de Sombra $y$ de Fertilizacio'n Nitrogenada; INTA: Santiago del Estero, Argentina, 2012; pp. 289-293.

64. Crestani, S.; Mendonça, H.; Ribeiro, F.N.; Frederico, M.M.; Almeida, E.X.d; Portela, F.A. Steers performance in dwarf elephant grass pastures alone or mixed with Arachis pintoi. Trop. Anim. Health Prod. 2013, 45, 1369-1374. [CrossRef] [PubMed]

65. De Goes, R.H.d.T.e.B.; Mancio, A.B.; de Paula Lana, R.; Alves, D.D.; Leão, M.I.; Silva, A.T.S. Recria de novilhos mestiços em pastagens de Brachiaria brizantha, com diferentes níveis de suplementação, na região Amazônica. Desempenho animal. Rev. Bras. Zootec. 2005, 34, 1740-1750. [CrossRef]

66. Hoffmann, A.; Moraes, E.H.B.K.; Mousquer, C.J.; Simioni, T.A.; Gomes, F.J; Ferreira, V.B.; Silva, H.M. Produção de Bovinos de Corte no Sistema de Pasto-Suplemento no Período Seco. Nativa 2014, 2, 119-130. [CrossRef]

67. Lesama, M.F.; Moojen, E.L. Produção animal em gramíneas de estação fria com fertilização nitrogenada ou associadas com leguminosa, com ou sem fertilização nitrogenada. Ciênc. Rural 1999, 29, 123-128. [CrossRef]

68. Latawiec, A.E.; Strassburg, B.B.N.; Valentim, J.F.; Ramos, F.; Alves-Pinto, H.N. Intensification of cattle ranching production systems: Socioeconomic and environmental synergies and risks in Brazil. Animal 2014, 8, 1255-1263. [CrossRef] [PubMed]

69. Angelsen, A. Policies for reduced deforestation and their impact on agricultural production. Proc. Natl. Acad. Sci. USA 2010, 107, 19639-19644. [CrossRef] [PubMed] 
70. Vale, P.M. The Conservation versus Production Trade-Off: Does Livestock Intensification Increase Deforestation? Evidence from the Brazilian Amazon; Working Paper No. 197. 2014. Available online: http://www.lse. ac.uk/GranthamInstitute/wp-content/uploads/2014/12/Working-Paper-174-Vale-2014.pdf (accessed on 16 April 2018).

71. Alix-Garcia, J.; Gibbs, H.K. Forest conservation effects of Brazil's zero deforestation cattle agreements undermined by leakage. Glob. Environ. Chang. 2017, 47, 201-217. [CrossRef]

72. Phalan, B.; Green, R.E.; Dicks, L.V.; Dotta, G.; Feniuk, C.; Lamb, A.; Strassburg, B.B.N.; Williams, D.R.; zu Ermgassen, E.K.H.J.; Balmford, A. How can higher-yield farming help to spare nature? Science 2016, 351, 450-451. [CrossRef] [PubMed]

73. Harfuch, L.; Palauro, G.; Zambianco, W.M. Economic Analysis of Investment for the Cattle Ranching Expansion; INPUT \& AGROICONE: São Paulo, Brazil, 2016; p. 8.

74. Valentim, J.F.; da Carneiro, J.C. Quebra da Dormência e Plantio de Puerária em Sistemas de Produção Agropecuários e Agroflorestais; Embrapa Acre-Sér. Anteriores INFOTECA-E: Rio Branco, Brazil, 1998.

75. Ministério da Agricultura, Pecuária e Abastecimento (MAPA). Plano mais Pecuária; Ministério da Agricultura, Pecuária e Abastecimento: Brasília, Brazil, 2014.

76. Latawiec, A.E.; Strassburg, B.B.N.; Silva, D.; Alves-Pinto, H.N.; Feltran-Barbieri, R.; Castro, A.; Iribarrem, A.; Rangel, M.C.; Kalif, K.A.B.; Gardner, T.; et al. Improving land management in Brazil: A perspective from producers. Agric. Ecosyst. Environ. 2017, 240, 276-286. [CrossRef]

77. Soares-Filho, B.; Rajão, R.; Merry, F.; Rodrigues, H.; Davis, J.; Lima, L.; Macedo, M.; Coe, M.; Carneiro, A.; Santiago, L. Brazil's Market for Trading Forest Certificates. PLoS ONE 2016, 11, e0152311. [CrossRef] [PubMed]

78. Newton, P.; Alves-Pinto, H.N.; Pinto, L.F.G. Certification, Forest Conservation, and Cattle: Theories and Evidence of Change in Brazil: Cattle certification in Brazil. Conserv. Lett. 2015, 8, 206-213. [CrossRef]

79. Lopes, D.; Lowery, S. Rural Credit in Brazil; 2017. Available online: http://www.forest-trends.org/ documents / files / doc_5016.pdf (accessed on 7 February 2017).

80. Gurgel, A.G.; Costa, C.F.; Barbosa, L.B.C.; Piha, D. Desafios e Restrições dos Produtores Rurais na Adoção de Tecnologias de Baixo Carbono ABC: Estudo de Caso em Alta Floresta, em Mato Grosso. Fundação Getulio Vargas (FGV) Centro de Agronegócio (GV Agro), Escola de Economia de São Paulo (EESP), Observatório ABC. 2017. Available online: http://observatorioabc.com.br/wp-content/uploads/2017/05/Sumario_ABC_ AltaFloresta_-1.pdf (accessed on 6 February 2017).

81. Gurgel, A.C.; Costa, C.F.; Belinky, A.; Monzoni, M.; Vendramini, A.; Rocha, F.C.; Martins, S.C. Análise dos Recursos do Programa $A B C$; Centro de Estudos em Sustentabilidade da Fundação Getulio Vargas, Centro de Agronegócio, Escola de Economia de São Paulo, \& Aliança pelo Climate Uso da Terra. 2014. Available online: https: / s3-sa-east-1.amazonaws.com/arquivos.gvces.com.br/arquivos_gvces/arquivos / 340/ObsABC_Relatorio2_AnaliseRecursosRegional_Completo.pdf (accessed on 28 April 2015).

82. Novo, A.L.M. Islands of Dairy in a Sea of Sugarcane: The Future of Family Dairy Farming in Brazil; Wageningen University: Wageningen, The Netherlands, 2012.

83. Garrett, R.; Gardner, T.; Morello, T.; Marchand, S.; Barlow, J.; Ezzine de Blas, D.; Ferreira, J.; Lees, A.; Parry, L. Explaining the persistence of low income and environmentally degrading land uses in the Brazilian Amazon. Ecol. Soc. 2017, 22. [CrossRef]

84. Ceballos, M.C.; Góis, K.C.R.; Sant'Anna, A.C.; Paranhos da Costa, M.J.R. Frequent handling of grazing beef cattle maintained under the rotational stocking method improves temperament over time. Anim. Prod. Sci. 2016. [CrossRef]

85. Pinto, L.F.G.; Hajjar, R.; Newton, P.; Agrawal, A.; Adshead, D.; Bini, D.; Bogaerts, M.; Cirhigiri, L.; Maguire-Rajpaul, V.A.; González-Chaves, A.; et al. Transitioning to More Sustainable, Low-Emissions Agriculture in Brazil; GGIAR, CIAT \& FutureEarth. 2016. Available online: https://cgspace.cgiar.org/handle/10568/ 75631 (accessed on 31 August 2017).

86. Martha, G.B.; Alves, E.; Contini, E. Land-saving approaches and beef production growth in Brazil. Agric. Syst. 2012, 110, 173-177. [CrossRef]

(C) 2018 by the authors. Licensee MDPI, Basel, Switzerland. This article is an open access article distributed under the terms and conditions of the Creative Commons Attribution (CC BY) license (http://creativecommons.org/licenses/by/4.0/). 